\title{
Alboran Basin, southern Spain-Part II: Neogene tectonic implications for the orogenic float model
}

\author{
M. Ballesteros, ${ }^{a^{*}}$, J. Rivera ${ }^{a}$, A. Muñoz ${ }^{b}$ A. Muñoz-Martín ${ }^{\text {c }}$, J. Acosta ${ }^{a}$, A. Carbóc ${ }^{c}$ E. Uchupi ${ }^{\text {d }}$ \\ ${ }^{a}$ Instituto Español de Oceanografía, Spain \\ bSecretaría General de Pesca Marítima, Spain \\ ${ }^{\mathrm{c}}$ Universidad Complutense de Madrid, Spain \\ ${ }^{\mathrm{d}}$ Woods Hole Oceanographic Institution, Spain
}

\begin{abstract}
We infer that the Alboran Basin, the first western Mediterranean Basin found after crossing Gibraltar, is an orogenic float underlained by a de' collement system, a multi-layered ductile shear extending from $10 \mathrm{~km}$ to between 30 and $40 \mathrm{~km}$ below sea level. This float was formed as consequence of the collision of the African-Eurasian plates in the Oligocene-late Miocene. Synchronous with this compression the float experienced basin wide crustal thinning and subsidence about $25 \mathrm{~m} /$ year ago by subcrustal processes. Since latest Miocene the float has undergone compression due to the continuous convergence of Eurasia and Africa. The faults created as a result of this compression are dominated by a conjugate system of northeast trending left-lateral and northwest right-lateral strike-slip faults. This deformation is taking place under a simple shear mechanism. Associated with the northwest and northeast lateral faults are zones of compression trending west and east of north extending from the base of the basin's north upper slope to the Alboran Ridge. The initial morphology of the Alboran Ridge on the southern side of the Alboran Basin was due to the construction of a volcanic edifice at the northeast end of the ridge and igneous activity along northeast trending fractures southwest of the edifice. At the northeast end of the Alboran Ridge motion along a right-lateral fault cutting across the ridge led to sediment collapse and the creation of a prominent embayment on the ridge's northwest flank. Deformation is more subdued in the western than in the eastern part of the Alboran Basin, a tectonic style due either to differences in sediment rheology or that the accommodation of the convergence of Africa and Iberia is more diffused and attenuated in the west than in the east.
\end{abstract}

Keywords: Alboran Ridge; Alboran Basin; Carbonate mounds; Conjugate faults; Motril and Adra anticlines; Orogenic float; Stress regime (pure and simple shear); Serrata-Carboneras Fault

\section{Introduction}

In a previous report (Muñoz et al., in press) we used multibeam echo sounding data supplemented by a few selected high resolution TOPAS seismic reflection profiles to define the geomorphology of the marine Alboran Basin, a structure located within the Alpine orogen off southern Spain and northern Morocco. In the present report we use these data to define the tectonic style of the basin. The Alpine orogen at the southern end of Spain and northern Morocco on which the Alboran Basin is superimposed consists of three Pre-Neogene crustal domains, the external zones (the south-Iberian and Maghrebian passive continental margins) composed of Mesozoic and Tertiary sedimentary rocks, the Flysch Trough Units consisting of nappes of Cretaceous-early Miocene sediments that were deposited on oceanic crust or very thin continental crust, and the Internal or Alboran Domain comprised of metamorphosed Palaeozoic and Mesozoic sediment thrust stack (Fig. 1; Comas et al., 1999). The thrust sheets of the Alboran Domain were transported outwards onto the

*Corresponding author.

E-mail address: maria.gomez@md.ieo.es (M. Ballesteros). 


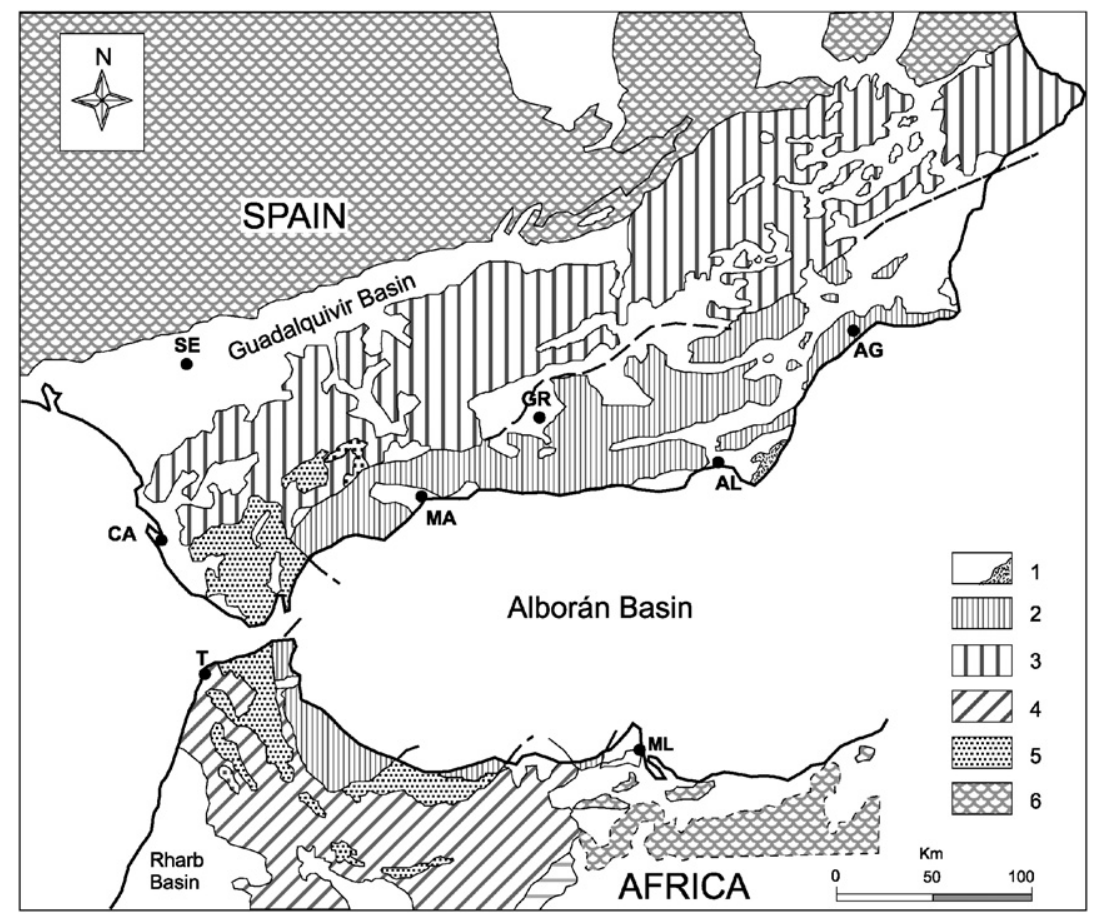

Fig. 1. Geologic setting of the Alboran Basin region. $\mathrm{AG}=$ Aguilas; $\mathrm{AL}=$ Almería $\mathrm{CA}=\mathrm{Cadiz} ; \mathrm{GR}=\mathrm{Granada} ; \mathrm{MA}=\mathrm{Malaga} ; \mathrm{ML}=\mathrm{Melilla}$; $\mathrm{T}=$ Tangier. Modified from Vegas (1992; Fig. 1) by Muñoz et al. (in press).

passive margins of Iberia and Morocco during the Oligocene and westward from latest Oligocene and early Miocene creating the peripheral Gibraltar Arc thrust belt. The domain underwent approximately $200 \mathrm{~km}$ of roughly north-south convergence between the mid-Oligocene and late Miocene and $50 \mathrm{~km}$ of northwest-southeast convergence from latest Tortonian (9-8 Ma) to the present (Comas et al., 1999 and references therein). Synchronous with this shortening of the peripheral belt of the Betic and Rif domains was extension within the Internal Domain, toward the south-southwest in the West Alboran Sub-Basin and toward the southeast in the East Alboran Sub-Basin (Comas et al., 1992). This extension led to the formation of the Intramontane Basins within the Alboran Domain and the present marine Alboran Basin (Shipboard Scientific Party, 1996). Comas et al. (1992) inferred that extension took place during latest Aquitanian-Burdigalian, Langhian-Serravalian and Tortonian with the middle Miocene episode leading to the development of major depocenters and the creation of mud diapirs in the West Alboran Sub-Basin.

Extension in the Alboran Domain ended in late Miocene. Since late Tortonian the area has been under compression producing folding, reverse fault inversions of former normal faults and strike-slip faults. This compression ranged from northwest-southeast during late Tortonian, north-south from late Tortonian to middle Pliocene and north-northwest-south-southeast during the rest of the Pliocene and Pleistocene (Comas et al., 1999). This tectonic shortening and concomitant progressive emergence of segments of the ancestral Alboran Basin reduced the basin to a $400 \times 200 \mathrm{~km}$ low straddling the African and Eurasian plate boundary (Platt and Vissers, 1989).

\section{Morphology}

The area of the Alboran Basin studied during the present investigation extends from $35^{\circ} 40^{\prime} \mathrm{N}$ to $36^{\circ} 50^{\prime} \mathrm{N}$ and from $2^{\circ} 10^{\prime} \mathrm{W}$ to $4^{\circ} 40^{\prime} \mathrm{W}$ (Figs. 2-4). Primary basin topographic features include the northern shelf, basin slope and apron, Habibas Escarpment, along the Yussulf Fault, and the Alboran Channel and Ridge. Secondary topography features include the submarine canyons in the basin north slope, the sides of the Alboran Ridge and Trough and Habibas escarpment, gravitational structures, mounds of unknown origin along the base of the northern slope, Miocene volcanic edifices and fault traces (Muñoz et al., in press). The northern shelf is $3-14 \mathrm{~km}$ wide with its seaward edge being at a depth of $100 \mathrm{~m}$ west of Cabo de Gata and $150-175 \mathrm{~m}$ off Cabo de Gata. The $1-4.5 \mathrm{~km}$ wide and $47-90 \mathrm{~m}$ high upper slope extending to a depth of 150-200 m west of Cabo de Gata and to $400 \mathrm{~m}$ off Cabo de Gata has a gradient of $1^{\circ}$ to $10-15^{\circ}$. The $7.5-19 \mathrm{~km}$ wide lower slope west of Almería Bay extends to a depth of $600 \mathrm{~m}$. On the east side of Almería Bay the lower slope is made up of two segments, an upper one extending from a depth of $400-700 \mathrm{~m}$ having a declivity of $1-3^{\circ}$ and a lower one extending to a depth of 1600 with a gradient that exceeds $24^{\circ}$.

The basin apron on the western side of the Alboran Basin extends to a depth of $1500 \mathrm{~m}$ from the base of the lower slope, terminates southward on the Albora ridge and 


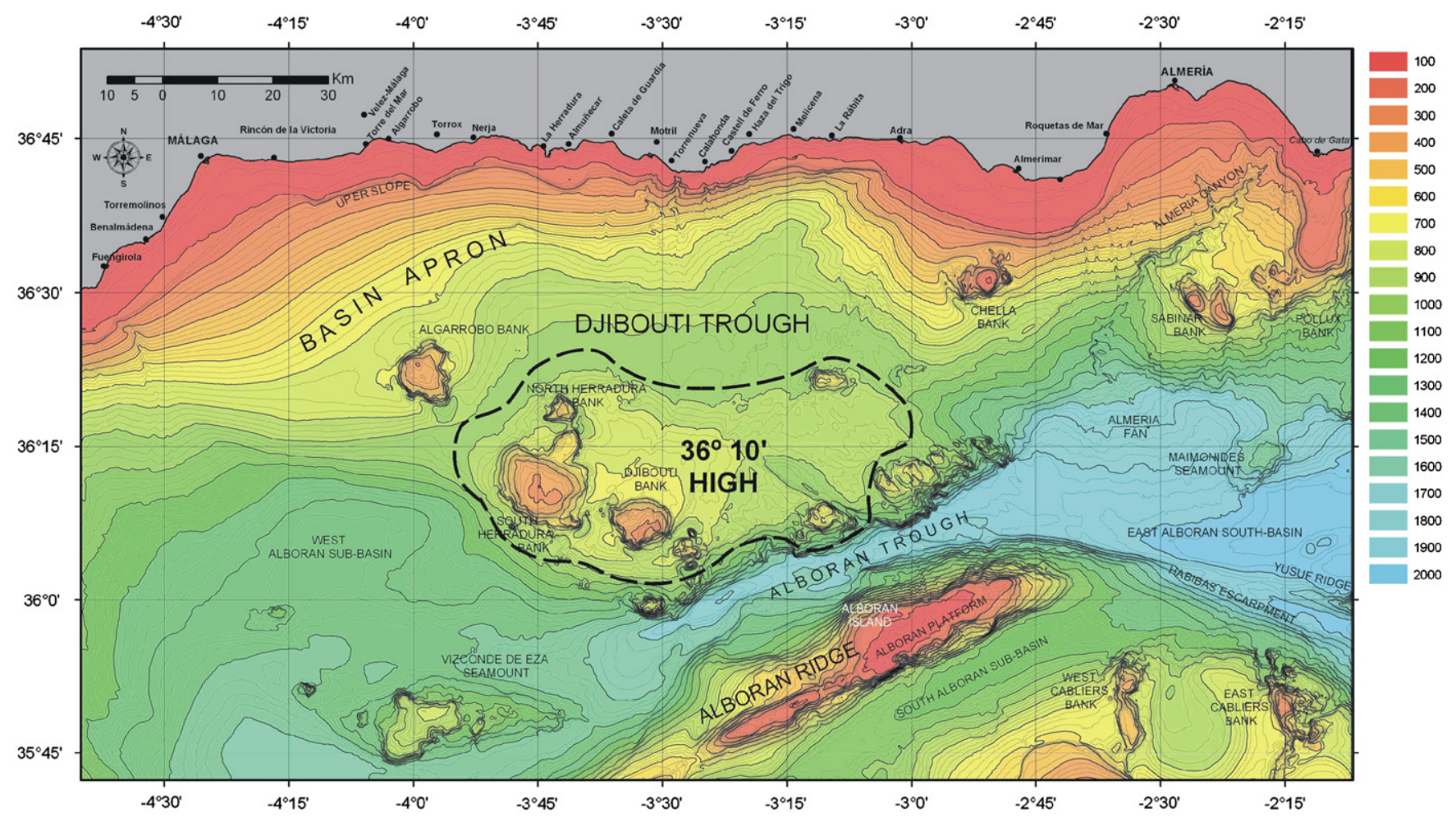

Fig. 2. Bathymetric chart of the Alboran Basin compiled from multi-beam acquired during the present investigation. Contour interval $25 \mathrm{~m}$. From Muñoz et al. (in press).

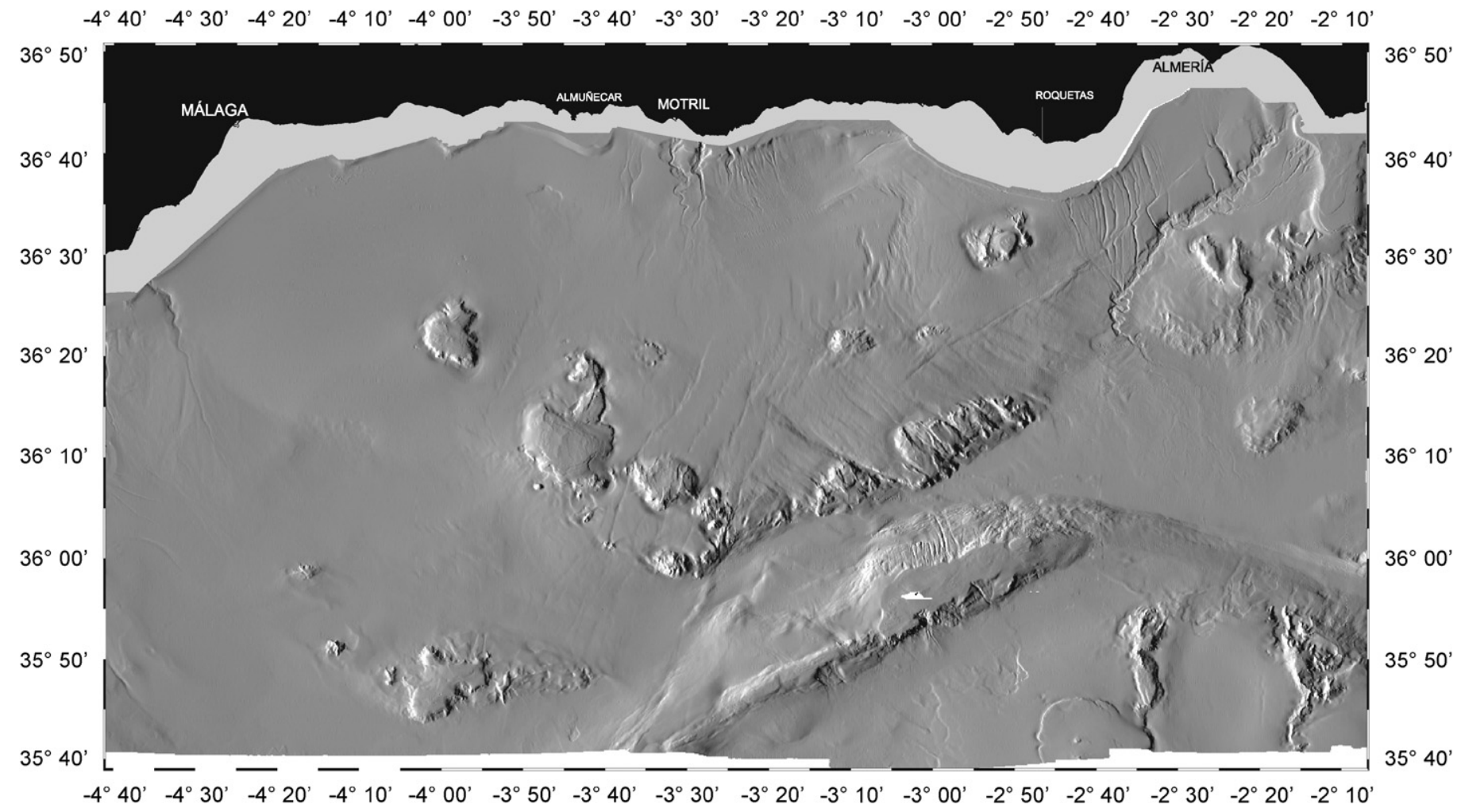

Fig. 3. Shaded relief map of the Alboran Basin compiled from multi-beam data. See Fig. 2 for names of prominent topographic features. From Muñoz et al. (in press).

has a gradient of $2-1^{\circ}$. A low in the western side of the apron, the West Alboran Sub-Basin, is defined by the $1200 \mathrm{~m}$ contour. In the center of the Alboran Basin, from $4^{\circ} \mathrm{W}$ to $2^{\circ} 45^{\prime} \mathrm{W}$, the apron is dominated by an east-west trending 6 to $17 \mathrm{~m}$ wide over $900 \mathrm{~m}$ deep trough that we have tentatively named the Djibouti Trough. South of the 


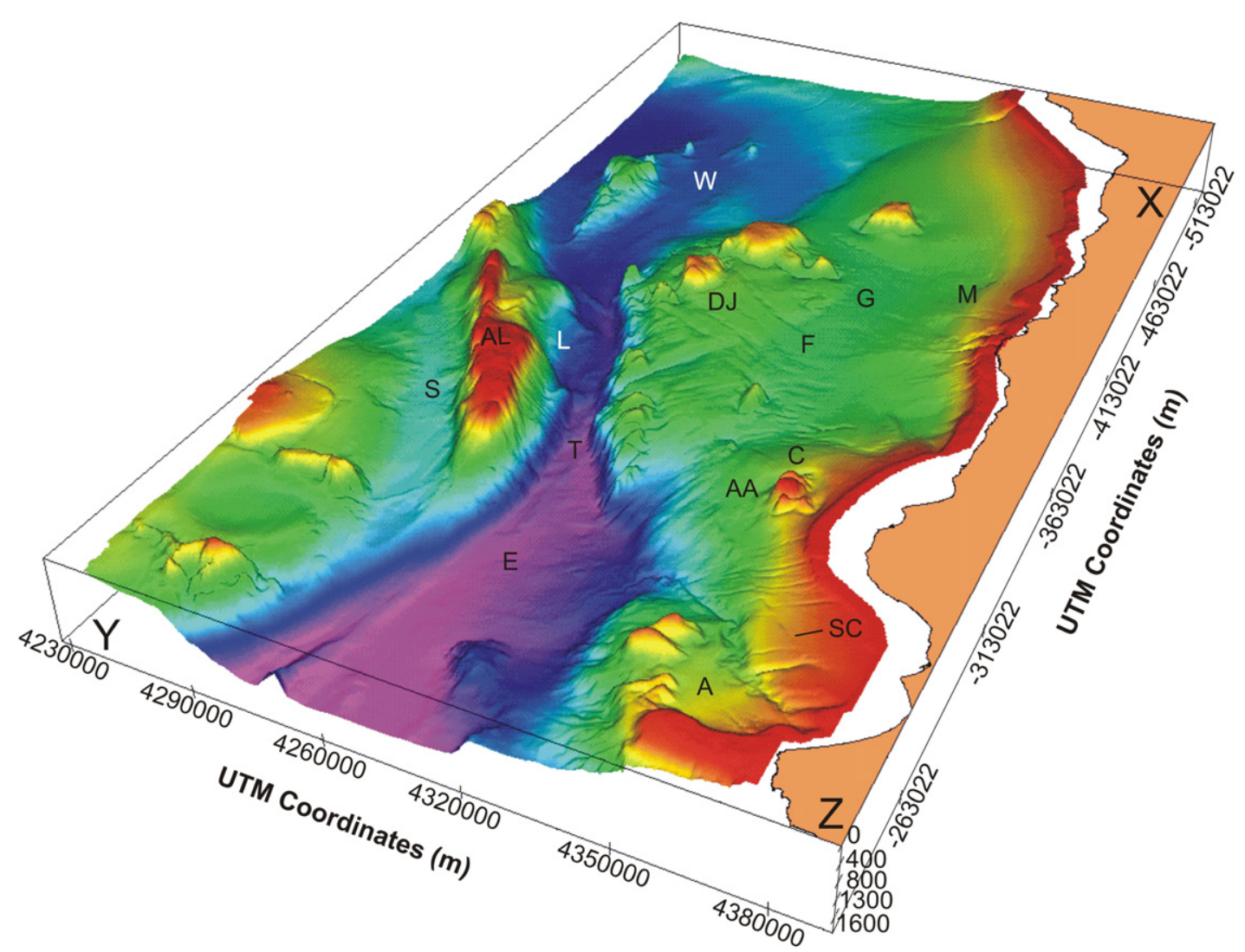

Fig. 4. The 3D diagram of Alboran Basin compiled from multi-beam data. This diagram images the northeast and northwest structures in the center of the basin. $\mathrm{A}=$ Almería Canyon; $\mathrm{AA}=$ Abra Anticline; $\mathrm{AL}=$ Alboran Ridge; $\mathrm{C}=$ Chella Bank; DJ = Djibouti Bank; $\mathrm{E}=\mathrm{East}$ Alboran Sub-Basin; $\mathrm{F}=$ Fault traces; $\mathrm{G}=$ Graben; $\mathrm{L}=$ Slide scar; $\mathrm{M}=$ Motril Anticline; $\mathrm{S}=$ South Alboran Sub-Basin; $\mathrm{SC}=\mathrm{Serrata}-\mathrm{Carboneras} \mathrm{Fault}$; $\mathrm{T}=\mathrm{Alboran}$ Channel; $\mathrm{W}=$ West Alboran Sub-Basin.

trough is the $<900 \mathrm{~m}$ deep high whose top is dominated by seamounts. We have named this feature the $36^{\circ} 10^{\prime} \mathrm{N}$ High (Fig. 2). The apron on the eastern side of the Alboran Basin is dominated by an over $1950 \mathrm{~m}$ deep $30 \mathrm{~km}$ wide and $57 \mathrm{~km}$ long low, the East Alboran Sub-Basin. The subbasin is flanked on the south by the Habibas Escarpment. On the southern part of the Alboran Basin is the $120 \mathrm{~km}$ long $4.5-8 \mathrm{~km}$ wide Alboran Ridge with its crest being less than $100 \mathrm{~m}$ deep. The ridge extends from Xauen Bank at $4^{\circ} 1^{\prime} \mathrm{W}, 35^{\circ} 20^{\prime} \mathrm{N}$ on the southwest to Habibas Escarpment on the northeast. The base of the ridge's northwest side is $1000-1800 \mathrm{~m}$ deep, has a gradient of $18-24^{\circ}$ and is indented by a $10 \mathrm{~km}$ wide northwest trending embayment near $3^{\circ} 15^{\prime} \mathrm{W}$. The ridge's southeast side is linear, has a declivity greater than $24^{\circ}$ and its base is at a depth of $1000 / 1100 \mathrm{~m}$. Northwest of the Alboran Ridge is the Alboran Channel. The northwest side of this low has a relief of 700-900 m, a gradient of $18-24^{\circ}$ and has a rough appearance being entrenched by narrow northwest trending gullies. Its floor is irregular characterized by a chain of low relief depressions. Southeast of the Alboran Ridge and Habibas Escarpment is the South Alboran Apron. Within this apron is the South Alboran Sub-Basin, a 6-111 km wide low along the southeast flank of Alboran Ridge. The sub-basin terminates northeastward against the
Habibas Escarpment and the $<400 \mathrm{~m}$ high East and West Cabliers ridges.

\section{Structural setting}

The main structural elements of the Alboran Basin, margins, basins and topographic highs, are the creation of Miocene crustal attenuation. The south facing basin margin displays a passive margin structural style consisting of sediment covered blocks that are tilted and faulted downward (Maldonado et al., 1992). The main structural highs in the center of the Alboran Basin are the $36^{\circ} 10^{\prime} \mathrm{N}$ High and the Alboran Ridge (Figs. 2-4). The east-west trending ellipsoid shaped $36^{\circ} 10^{\prime} \mathrm{N}$ High, elevated along north and south facing slopes, is made up mostly of Alboran Domain metamorphic rocks whose relief has been accentuated by the emplacement of volcanic edifices. The southwest end of the Alboran Ridge consists of a volcanic core covered by a faulted Pliocene-Quaternary sequence. The volcanic rocks at northeast end of the high lack a significant sediment cover. Between the $36^{\circ} 10^{\prime} \mathrm{N}$ High and the Alboran Ridge is the $100 \mathrm{~km}$ long and $4.5-8 \mathrm{~km}$ wide Alboran Channel. A multi-channel seismic reflection profile recorded by Comas et al. (1995) across the irregular southeast slope of the $36^{\circ} 10^{\prime} \mathrm{N}$ High, the northwest side of 
the Alboran Channel, suggests that the country rock on the scarp consists of Alboran Domain (metamorphic basement); possibly pre-rift and syn-rift sediments also may be present along the strike of the scarp. These units are capped in places by Neogene volcanics both of which are covered by a discontinuous thin veneer of Holocene sediments. A profile recorded along the axis of the Alboran Channel by Comas et al. (1995) shows this same basement broken into grabens and half-grabens, probably trending northwest-southeast, underlie the Alboran Channel. The grabens are filled with syn-rift deposits about 1.0 second two-way travel time $(1.5 \mathrm{~km}$ assuming a velocity of $3 \mathrm{~km} / \mathrm{s})$ or less thick truncated by the Messinian unconformity. Above the unconformity is a Pliocene to Pleistocene litho-seismic unit with a maximum thickness of $2 \mathrm{~s}$ two way travel time ( $2 \mathrm{~km}$ assuming a velocity of $2 \mathrm{~km} / \mathrm{s})$. Differences in elevation between the rifted terrain in the Alboran Channel and that along the southwest side of the $36^{\circ} 10^{\prime} \mathrm{N}$ High is due to recent uplift and tilting northward of the high relative to the Alboran Channel.

The rifted tectonic style in the Alboran Channel extends eastward into the East Alboran Sub-Basin to within $27 \mathrm{~km}$ of Maimonides Seamount (Comas et al., 1995). From there to the seamount basement is in the form of a smooth surface platform that slowly rises from a depth of 4-3 s below sea level two way travel time. Maimonides Seamount is located at the crest of a basement fault scarp along which this platform descends eastward to a second platform at a depth of about $5 \mathrm{~s}$ below sea level. From there the second platform gradually rises to a depth $3.6 \mathrm{~s}$ over a distance of $23 \mathrm{~km}$. At that point basement again drops to $4-5 \mathrm{~s}$ below sea level and displays a rifted tectonic style. This rifted terrain extends eastward for a distance of $56 \mathrm{~km}$ where it gives way abruptly to the oceanic basement of the South Balearic Basin. The platform segment west of Maimonides Seamount is covered by a hummocky surfaced sequence about $1.0 \mathrm{~s}$ thick or $1 \mathrm{~km}$ thick assuming a velocity of $2 \mathrm{~km} / \mathrm{s}$; reflector $\mathrm{M}$, the Messinian unconformity, is missing in this section (Comas et al., 1995). The sediment cover in the lower platform east of Maimonides consists of a $1.0-0.6 \mathrm{~s}$ thick unit (1.0-0.6 km thick) below Horizon $\mathrm{M}$ and $0.6 \mathrm{~s}$ thick $(0.6 \mathrm{~km}$ thick) unit above $\mathrm{M}$. The rifted metamorphic basement east of the lower platform is covered by $0.7 \mathrm{~s}(1.05 \mathrm{~km})$ of syn-rift sediments, $0-1.2 \mathrm{~s}(0-1.2 \mathrm{~km})$ of Messinian and older deposits and about $1.0 \mathrm{~s}(1 \mathrm{~km})$ of post-Messinian sediments. About $1.0-1.5 \mathrm{~s}(1.0-1.5 \mathrm{~km})$ of pre-Messinian and Messinian sediment and evaporites and $1.0-0.5 \mathrm{~s}(1.0-0.5 \mathrm{~km})$ of Pliocene-Quaternary deposits cover the South Balearic oceanic basement east of the lower platform (Comas et al., 1995). A north-south trending multi-channel reflection profile recorded by Watts et al. (1993) shows that the smooth basement in the vicinity of Maimonides Seamount basement extends to the Habibas Escarpment. This suggests that the East Alboran Sub-Basin is underlained by a basement lacking any significant relief. Neither Comas et al. (1995) or Watts et al. (1993) considered the possibility that the smooth basement in the East Alboran Sub-Basin may be volcanics resting on rifted continental basement.

\section{Neotectonics}

\subsection{Compression}

The shaded relief map in Fig. 3, the 3D map in Fig. 4, their morpho-tectonic interpretation in Fig. 5 in conjunction with high resolution seismic reflection TOPAS profiles allows one to appreciate the extent of linear topographic features and broad rises affecting the sea floor of the Alboran Basin. These features, which are limited to part of the Alboran Basin east of $3^{\circ} 40^{\prime} \mathrm{W}$, have five topographic expressions, broad rises, scarps, narrow linear furrows, a chain of small lenticular lows and a few isolated rectangular depressions. We infer that these features are the expressions of warping, faulting and mass wasting and as these dislocations affect the sea floor they are of recent geologic age. A multi-channel seismic reflection profile described by Vegas et al. (1995, Fig. 5) suggests that basement (Alboran Domain) may be involved in the warping. This profile cuts obliquely across the Djibouti Trough and displays a subdued anticlinal structure at the southwest end of the profile south of Motril and another at the northeast end of the profile southeast of Adra. This last structure we have named the Adra Anticline (Fig. 5). In their Fig. 5 Vegas et al. (1995) identify basement as the length of the profile suggesting that it is involved in the Motril and Adra anticlines, but examination of their published profile makes such an identification questionable. However, seismic activity in the region (Fig. 5) supports Vegas et al. contention that basement is involved in the formation of the anticlines. As these features have sea floor expression indicates that were formed recently, probably as a result of compression from the northwest during the Plio-Holocene.

\subsubsection{Motril Anticline}

The more subdued structure, Motril anticline, appears to trend west of north and extends from the base of the upper basin slope at a depth of $200 \mathrm{~m}$ to the lower basin apron at a depth of $900 \mathrm{~m}$. Deformation on this structure can be traced to the $\mathrm{M}$ reflector (Messinian Unconformity) in the seismic reflection profile described by Vegas et al. (1995). This structure appears to be part of a tectonic block that Pérez-Belzuz (1999) named the Gualchos Block. The block is best developed on the shelf and upper slope whose prominent structure is the Gauchos Fault. Although this fault has not been active since early Pliocene, it was affected by Quaternary tectonism on the Motril Anticline located less than $20 \mathrm{~km}$ southeast of the fault (Pérez-Belzuz, 1999). The Motril Anticline trends from $\mathrm{N} 45^{\circ} \mathrm{E}$ to $\mathrm{S} 65^{\circ} \mathrm{W}$, is asymmetrical in cross-section, is about $20-28 \mathrm{~km}$ wide, $45 \mathrm{~km}$ long, its crestal zone ranges in depth from 200 to $950 \mathrm{~m}$ and plunges southwestward 
(Fig. 5). It narrows southwestward abutting the side of North Herradura Bank.

\subsubsection{Syncline}

The syncline between the Adra and Motril Anticline is about $30 \mathrm{~km}$ long and is convex westward (Figs. 5 and 9). The syncline can be traced across the basin apron at a depth of $900 \mathrm{~m}$ to the base of the upper slope at a depth of $200 \mathrm{~m}$. It probably extends across the shelf to land as a structural low between Motril and Adra anticlines (Figs. 5 and 9). Other zones of compression in the Alboran Basin are located southeast and southwest of the SerrataCarboneras Fault (Fig. 5). Both of these areas are dominated by northwest striking in en echelon faults with the sediments between the faults being tightly folded. Such features are common in strike-slip faults (Wilcox et al., 1973). This structural domain is discussed below in the section on northwest trending right-lateral faults.

\subsubsection{Adra Anticline}

The crest of the Adra Anticline off Campo de Dalías displays a high level of seismic activity (Fig. 5). MarínLechado et al. (2005) stated that this seismicity is concentrated in the upper $10 \mathrm{~km}$ and displays a northwest-southeast orientation. In some cases this distribution coincides with Quaternary faults in Campo de Dalías. Matínez-Díaz and Hernández-Enrile (1996), for example, stated that the west of north Adra-Berja fault zone along the west side of the Campo de Dalías Basin extends offshore and that the area was affected by two earthquakes in 1993-1994. The one $10 \mathrm{~km}$ east of Adra had a magnitude of 5.0 and the one offshore, $30 \mathrm{~km}$ southeast from the first one, had a magnitude of 4.9. Projections of the two main shocks and the 350 after shocks onto a structure map of the area by Martínez-Díaz and Hernández-Enrile (2004) suggests that Adra-Berja fault extends onto the offshore Adra Anticline. This cluster of shocks and aftershocks are located in a block, the North-Alboran block, bounded between the northeast-southwest trending Serrata-Carboneras Fault and the east-west Alpujarras Fault (on land, out of our maps) (Martínez Díaz and Hernández-Enrile, 2004). In our shaded map (Fig. 3) the trace of the Adra Berja Fault on the basin apron may be represented by a shallow northeast trending graben southeast of the Chella-Ane Banks complex. The Adra Anticline also appears to be associated with two $\mathrm{S} 165^{\circ} \mathrm{E}$ trending seismic zones east of Adra and south of Campo de Dalías.

Analyses of the epicenter distribution on the Adra Anticline suggests the presence of a low-angle fault, that the fault has a seafloor expression, that it dips $30^{\circ}$ northward and that it bottoms out on the décollement surface at a depth of $10 \mathrm{~km}$ (Marín-Lechado et al., 2005). This fault may be the one propagating northwestward from the moat surrounding Chella Bank or it may be a fault associated with the northwest trending folds northwest of Chella Bank (Fig. 5). If so then the folds are located in the upper block of the crustal detachment north dipping fault.
The northwest flank of the Adra Anticline as imaged in the multi-channel described by Vegas et al. (1995) indicates that compression affects the Plio-Quaternary sequence indicating its youth. According to Pérez-Belzuz (1999) periods of maximum activity in the fold was during early and late Quaternary.

Along the Adra Anticline crest are five seamounts, Chella, Ane and NW on the basin slope, another on the basin apron and a fifth on the northern edge of the $36^{\circ} 10^{\prime} \mathrm{N}$ High. Along the southeast side of the anticline is the left-lateral Serrata-Carboneras Fault, northwest aligned lineations that appear to be fractures and a northwest trending right-lateral fault. The anticline terminates southwestward on the gap separating the $36^{\circ} 10^{\prime} \mathrm{N}$ High from the basin slope southwest of Cabo de Gata platform and the southern flank of the $36^{\circ} 10^{\prime} \mathrm{N}$ (Fig. 2). Toward the north and northeast the anticline may extend beneath the shelf to the Neogene Campo de Dalías Basin. Our study did not extend onto the shelf off Adra, but the geologic map of the Almería-Garrucha-Chella-Los Genoveses continental shelf compiled by Medialdea Vega et al. (1982) shows a zone of normal faults, mainly trending northwestward, extending from the shoreline to the shelf's edge from Adra to Almería.

If the Adra Anticline extends to Campo de Dalías it may join there a major anticline (Fig. 5) described by Pérez-Belzuz (1999). According to Rodríguez-Fernández and Martín-Penela (1993) the anticline in Campo de Dalías trends $70^{\circ} \mathrm{N}-80^{\circ} \mathrm{E}$ so if Adra anticline does join it, then the structure undergoes a drastic change in trend from northeast to east or the two structures are separated by a fault. The fold in the Campo de Dalías Basin affects basement and pre-Messinian sediments with the undisturbed Messinian and Pliocene strata filling the basins on either side of the fold. The fold was formed as consequence of a N-S compression at the end of the Tortonian that uplifted the adjacent sierras (RodríguezFernández and Martín-Penela, 1993). They stated that this compressive event created a trough along the SerrataCarboneras Fault that controlled Messinian sedimentation along the fault.

Faults along the northwest flank of the Adra and Motril anticlines and the syncline between them display morphology of a chain of short linear segments displaced laterally with respect to one another with each segment displays evidence of extension (Figs. 6 and 7). The disconnected depressions are aligned obliquely to the trend of the fold structures and range from narrow linear to elliptical to circular depressions resembling pockmarks creating by gas venting. The three western most fault traces give way northward to north-south graben structures (Fig. 3). On the easternmost fault trace that can be traced to the Alboran Basin's north slope the linear depressions diverge with one branch trending slightly west of north and the other north and displaying an anastomising pattern resembling a braided stream. Topographically the anastomising features resemble grabens created by gravity-driven 


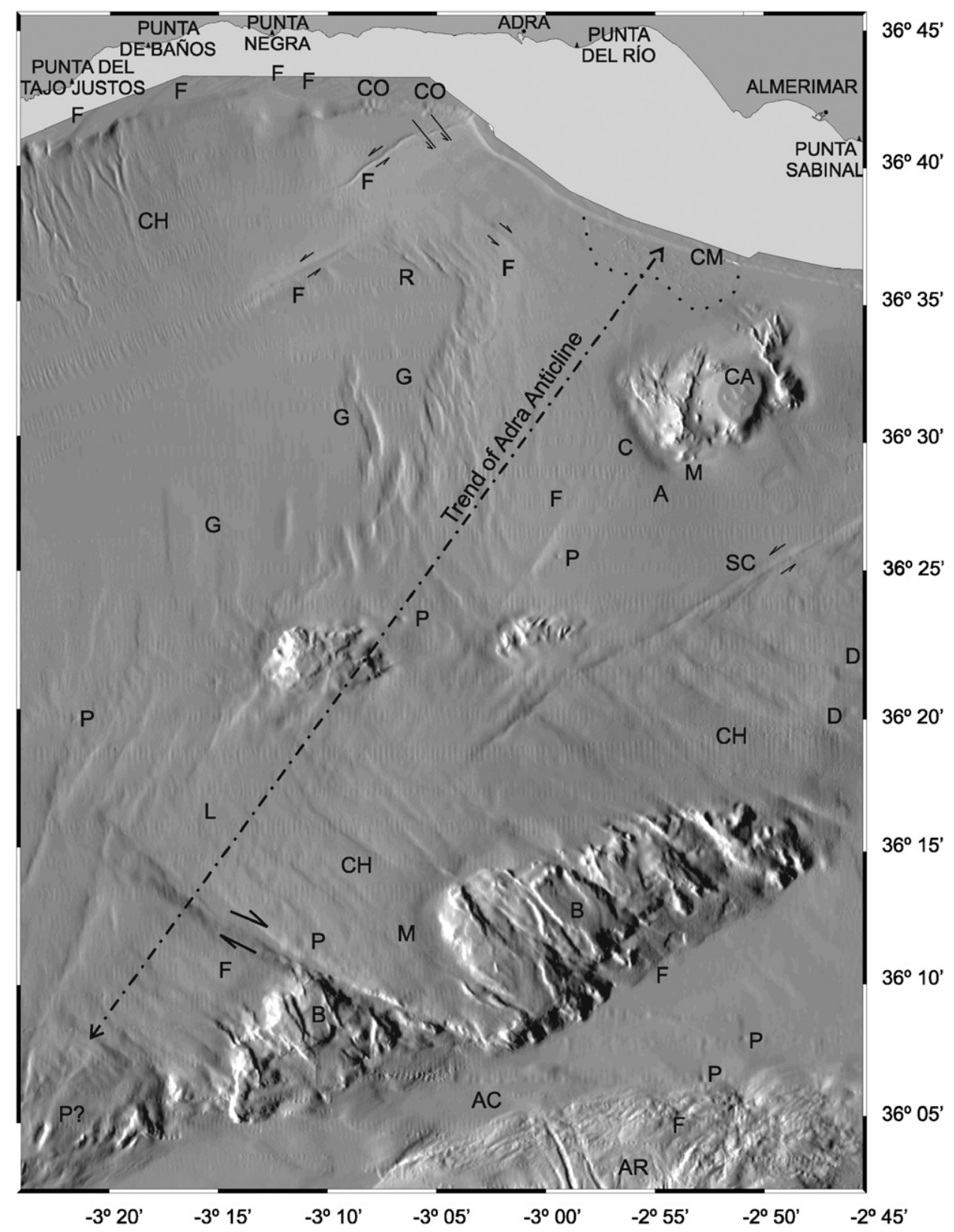

Fig. 6. Shaped relief diagram illustrating the morphology of a segment of the Alboran Basin extending from the Alboran Ridge to the basin shelf. $\mathrm{AC}=$ Alboran Channel; $\mathrm{AR}=$ Alboran Ridge; $\mathrm{B}=$ basement (Alboran Domain); $\mathrm{C}=$ Chella Bank surrounded by a rectangular shaped moat; $\mathrm{CA}=$ carbonate cap on crest of Chella; $\mathrm{CH}=$ channels. These lineations are inferred to the result of erosion by turbidity currents on the southeast slope of Adra Anticline; $\mathrm{CM}=$ carbonate mounds; $\mathrm{CO}=$ slumps; $\mathrm{D}=$ depressions; mega-pockmarks; $\mathrm{F}=$ faults; $\mathrm{G}=$ grabens; $\mathrm{M}=$ moats created by bottom current erosion and faulting in Chella Bank; note northeast to north trending narrow depressions imaged by TOPAS profile 157 (Fig. 6). These features are of extensional origin. $\mathrm{P}=$ pockmark due to gas venting; $\mathrm{R}=$ northwest trending ridges due to compression (see Line 159, Fig. 8); $\mathrm{SC}=\mathrm{Serrata}-\mathrm{Carboneras}$ Fault. See Fig. 12 for location of diagram.

gliding and spreading along an evaporite layer deposited over a basement steps in the Ligurian-Provençal Basin in the northwest Mediterranean (Maillard et al., 2003) and above salt in the Angolan passive margin (Fort et al., 2004). Some of the features associated with the northwest flank of Adra Anticline that have seafloor expression were inferred by Comas et al. $(1992,1995)$ to be the creation of north-south compression that spans until late Pliocene or even now. However, the north, northeast and northwest trends and their association with the fold structures led us also to reject such an origin. We infer that these features are former extensional structures associated with the west to northwest compression that formed the folds and that the structures have undergone inversion due to recent northwest-southeast compression.

At their northern end the structures along the northwest flank of the Adra Anticline give way abruptly to northwest aligned narrow folds and synclines parallel to a northwest right-lateral fault (Fig. 6). These folds terminate northwestward on a northeast trending left-lateral fault trace 


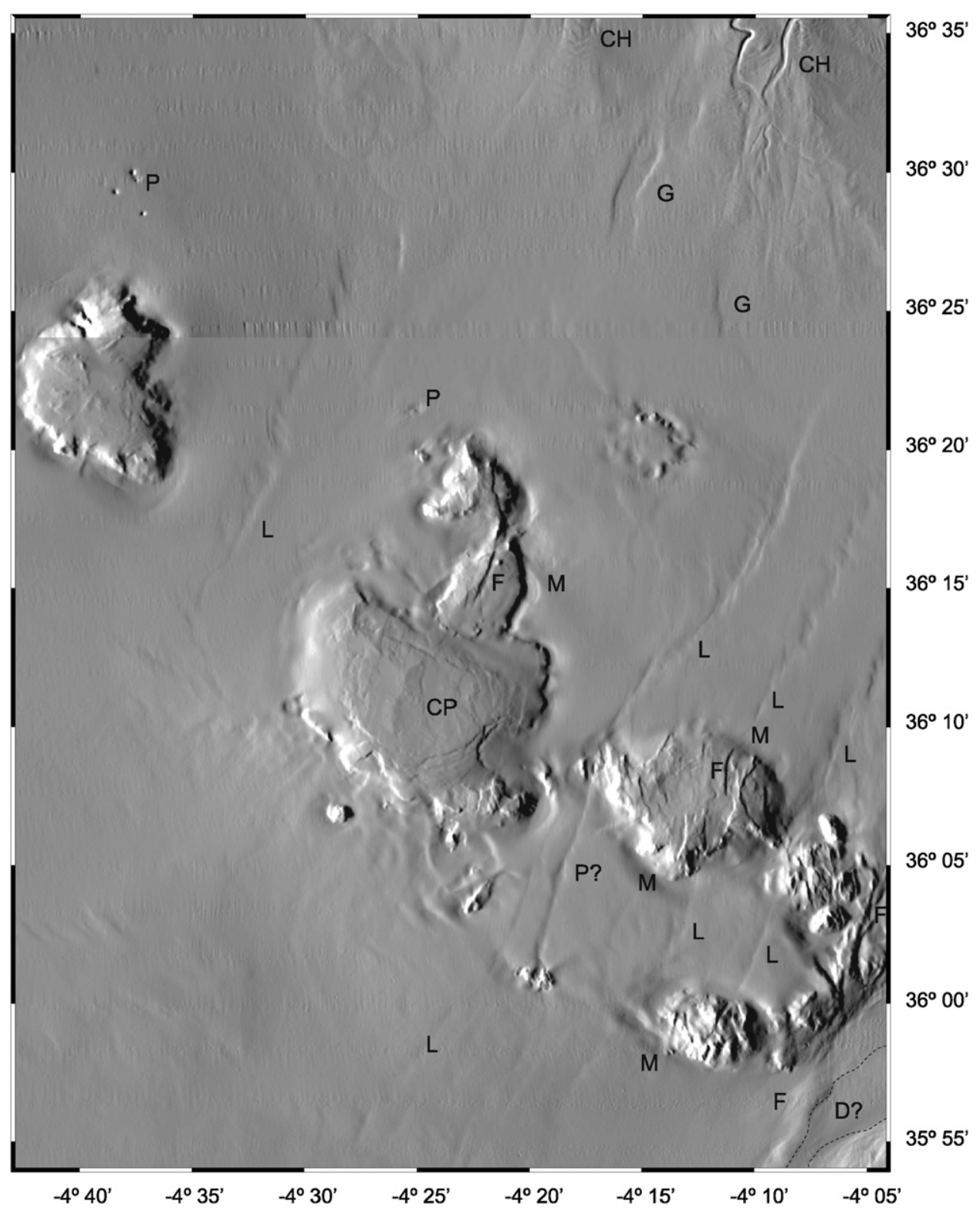

Fig. 7. Shaded relief diagram of a segment of the Alboran Basin apron in the vicinity of the Herradura Seamounts. $\mathrm{CH}=$ channels; $\mathrm{CP}=$ carbonate cap; $\mathrm{F}=$ faults; $\mathrm{G}=$ grabens; $\mathrm{M}=$ moat; $\mathrm{P}, \mathrm{P}$ ? = pockmarks; D? = deformed sediments. Note chain of depressions (L) along fractures. We infer that these features are mainly of extensional origin although gas venting may have contributed to their formation. See Fig. 12 for location of diagram.

(Fig. 6). A seismic reflection profile across this fault by Comas et al. (1992) indicates that motion along the fault is partially transpressive northwestward. Comas et al. (1992) inferred that this compression is due to the inversion of a previous normal fault, an inversion that supposedly took place during a post-rift compressional phase from latest Turonian to Holocene. This deformation supposedly produced folding, strike-slip faulting and inversion of existing normal faults by a roughly north-south compression. However, the northeast trend of the fault suggests that such compression must have been northwestsoutheast, not north-south. Such a trend is supported by earthquake focal mechanisms that indicate that the present day stress field around the Bétic-Rif cordilleras is compressional from the northwest (Galindo-Zaldívar et al., 1993).

The uniqueness of the morphology of the Adra Anticline is clearly imaged by the TOPAS profiles in Figs. 8-12. The southeast end of Line 150 (Fig. 8) indicates that the fault zone is characterized by a complex geometry of compression and extensional structures. Farther northeast, along Line 149 (Fig. 8), the fault zone is represented by a $\mathrm{V}$-shaped notch southeast of which is a zone of faulting and compression and Line 151 (Fig. 8) images a faulted fold complex. Line 153, crossing a small seamount at $36^{\circ} 20^{\prime} \mathrm{N}$, shows a normal fault system, the moat surrounding the seamount, and a faulted folded high east of the seamount (Fig. 9). This folded terrain is within the 

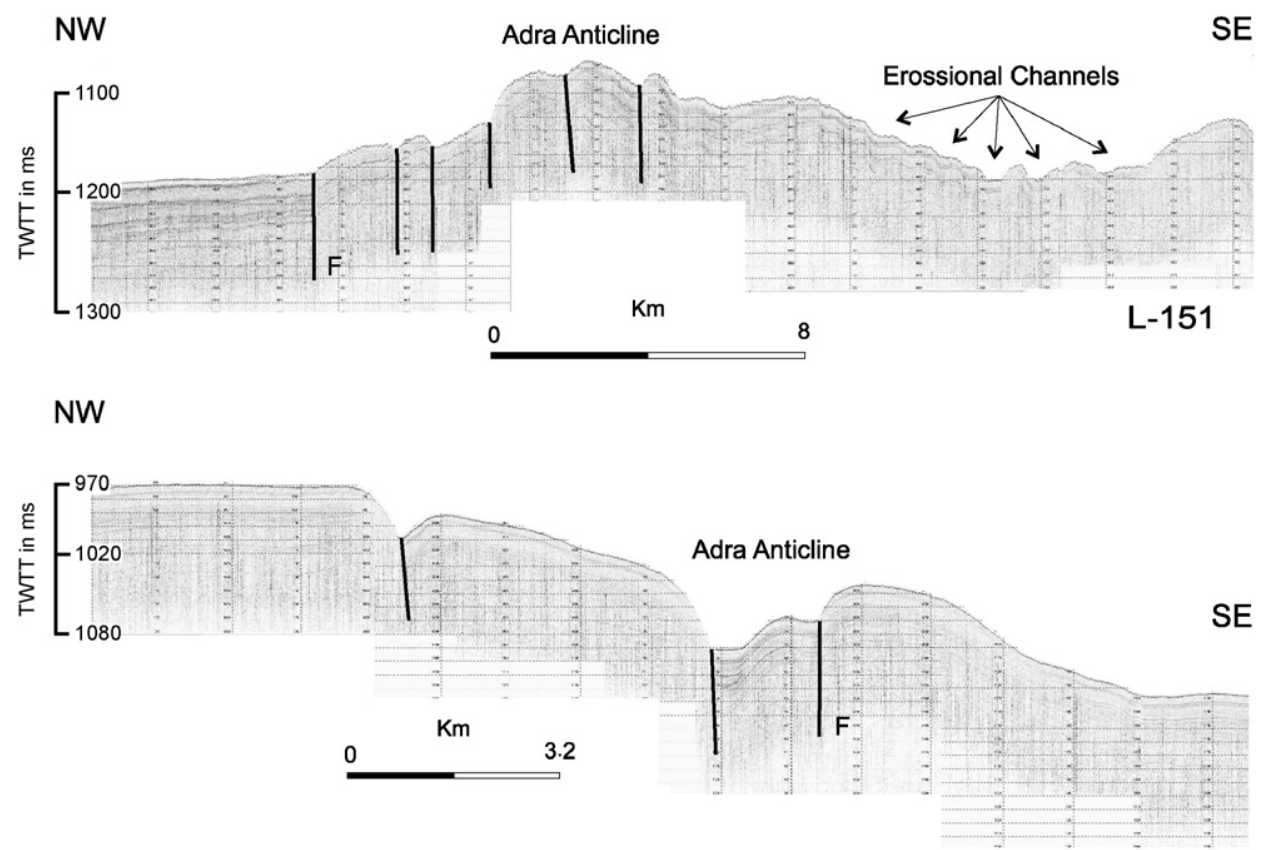

L-149

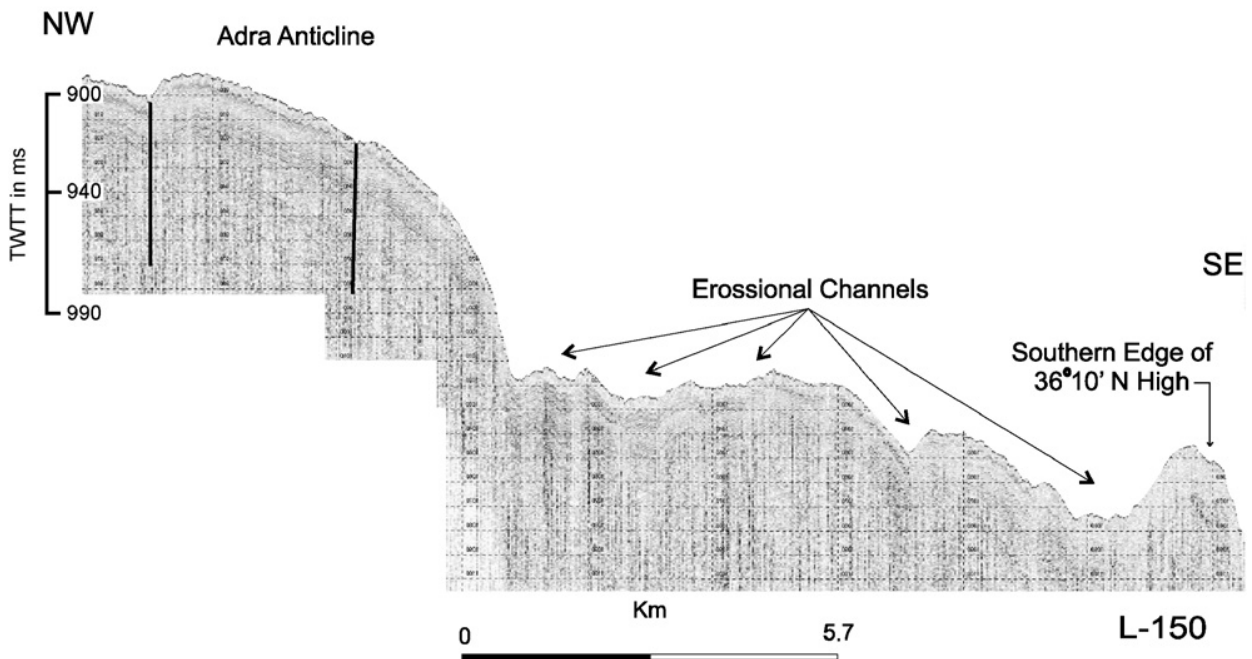

Fig. 8. TOPAS seismic reflection profiles 151, 149 and 150. See Fig. 12 for locations of profiles. F = fault. We infer that the lows on the southeast side of Profile 150 are of erosional origin.

northwest trending lineations southeast and southwest of the Serrata-Carboneras Fault (Fig. 5). The most striking features of the zone are those along Lines 157 and 159 (Fig. 9). At the northwest end of Line 157 is a structural low bordered on the southeast by a structural flat-topped high. Sediments in the structural low consist of two units separated by an unconformity with the sediments below the unconformity being folded. Beyond the high are seven narrow highs and lows that are the creation of extension. Line 159 crossing the north end of the Adra Anticline consists of a northwest structural trough at its northwest end, a folded and faulted broad rise in its center associated with Chella Seamount and the faulted crest of the Adras Anticline at the southeast of the line. Faulting along the profile is dominated by high angle normal faults. A TOPAS profile extending up the crest of the anticline to base of the continental slope (Line 36, Fig. 10) and another extending to the moat surrounding Chella Bank (Line 50, Fig. 10) demonstrate that this complex terrain of highs and lows along the flank of the Chella Bank also are the creation of extension within the compressional regime that formed the Adras anticline. Lines 146 and 148, on the western edge of the fault zone associated with the Adras Anticline, also demonstrate that the lows are a consequence of a combination of extension associated with the compression that formed the fold (Fig. 11).

\subsubsection{Other zones of compression}

Other zones of compression in the Alboran Basin are located southeast and southwest of the Serrata-Carboneras 


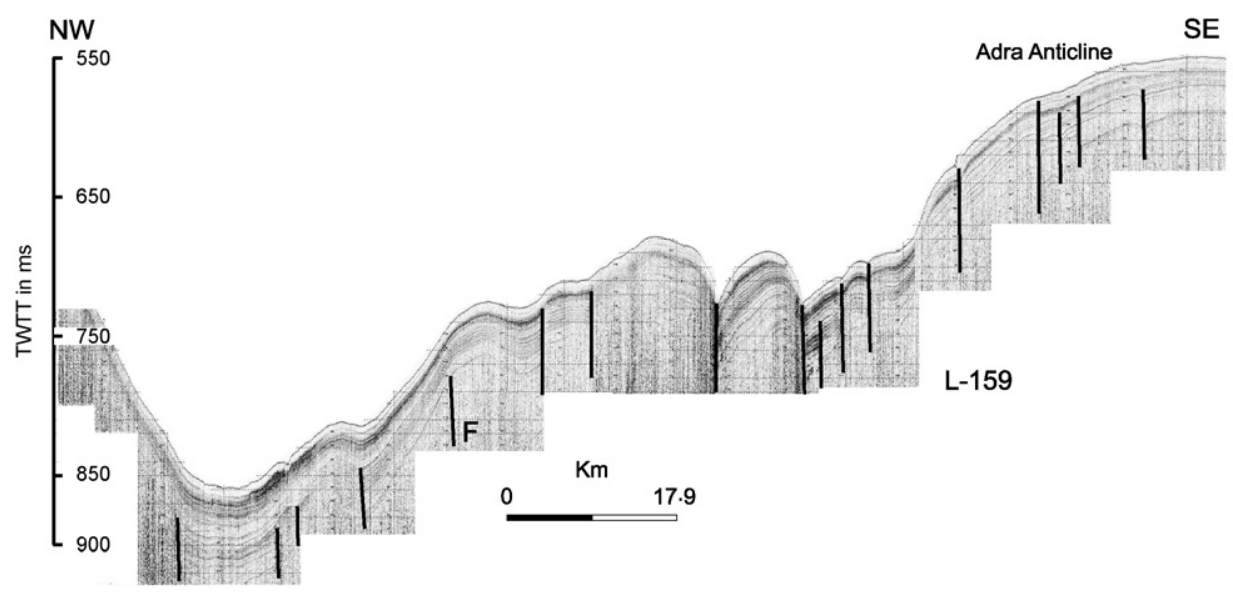

NW
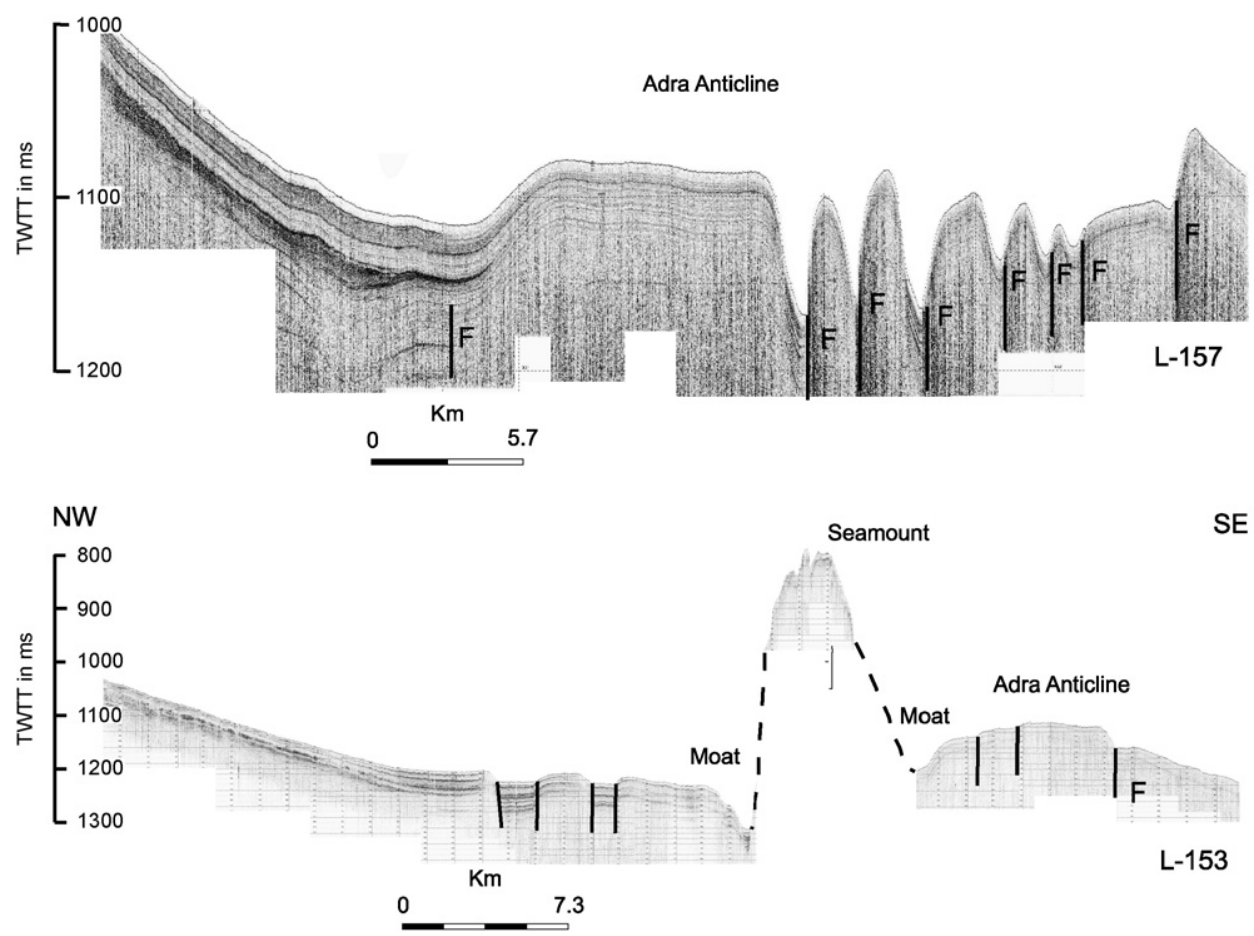

Fig. 9. TOPAS seismic reflection profiles $159,157,153$. See Fig. 12 for locations of Profiles. $F=$ fault. The unusual morphology displayed by Line 157 is due to closely spaced listric faults and the steep tilting of the intervening blocks.

Fault and along the flanks of the Alboran Ridge (Fig. 5). The areas southeast and southwest of the SerrataCarboneras Fault are dominated by northwest striking en enchelon faults/fractures with the sediments between these structures being tightly folded. Such features are common in strike-slip faults (Wilcox et al., 1973).

Another area of compression in the Alboran Basin occurs on the northwest side of the Alboran Ridge occurs west of $3^{\circ} 15^{\prime} \mathrm{W}$ (Fig. 14; Campos et al., 1992). This zone of compression is where a northeast trending left-lateral fault, possible southwest extension of the Serrata-Carboneras Fault, intersects the northwest flank of the Alboran Ridge. At the point of intersection the fault turns southwestward paralleling the northwest flank of the Alboran Ridge.
Multi-channel seismic reflection profiles recorded by Bourgois et al. (1992) indicate that compression of the sediment apron on the northwest flank of the Alboran Ridge extends southwest of $3^{\circ} 50^{\prime} \mathrm{W}$. Whereas the northwest side of the Alboran Ridge only displays evidence of compression west of $3^{\circ} 15^{\prime} \mathrm{W}$, deformation appears to be present in the length of the ridge's southeast flank. A multichannel seismic reflection profile obtained by Watts et al. (1993) images a zone of compression about $4.5 \mathrm{~km}$ from the base of the Alboran Ridge (Fig. 14). This deformed section near $3^{\circ} 20^{\prime} \mathrm{W}$ is at the distal end of a fan-shaped sediment wedge onlapping the southeast side of the Alboran Ridge. Watts et al. (1993) stated that GLORIA side-scan data indicates that this $5 \mathrm{~km}$ wide zone extends $50 \mathrm{~km}$ laterally 

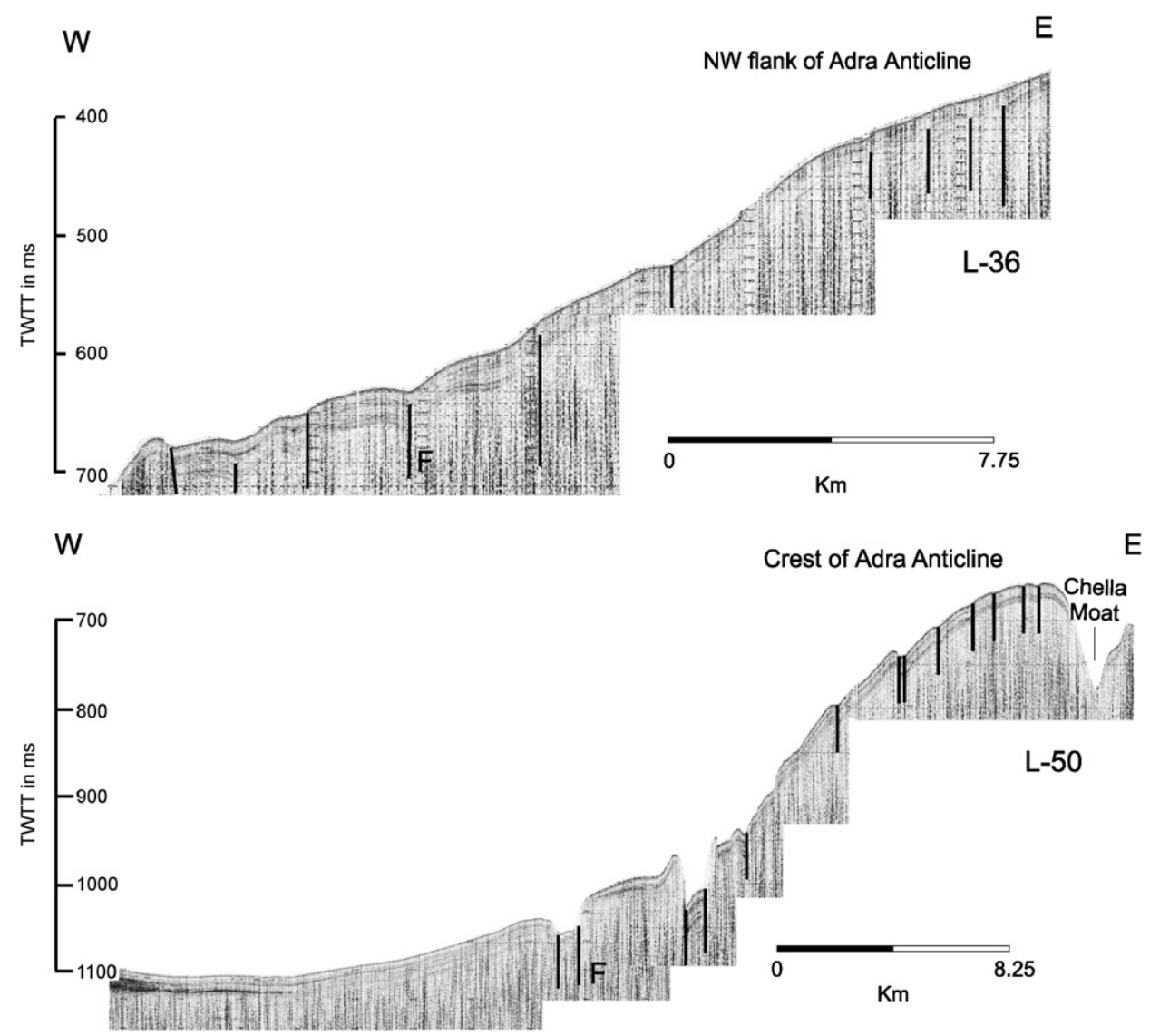

Fig. 10. TOPAS seismic reflection profiles 36 and 50. See Fig. 12 for locations of profiles $\mathrm{F}=$ fault.

on either side of their multi-channel seismic reflection line and that it appears to be related to left-lateral transpression. We, however, infer that this fault, like all faults trending approximately east-west in the Alboran Basin are right-lateral (see Section 6) as are the faults trending northwest-southeast.

\subsection{Faults}

\subsubsection{East-west faults}

The linear traces having seafloor expression that we infer to represent recent faults display four trends: eastwest, east of north, northeast and northwest (Fig. 5). An example of faults trending roughly east-west is the dislocation along the north shelf's edge (Fig. 5), a fault whose continuity is disrupted by northwest right-lateral strike-slip faults. Some of the strike-slip structures extend across the shelf onto the coastal zone. If they extend beyond the upper basin slope to the apron they have no topographic expression. These secondary faults have led to the creation of spur-like projections along the shelf's edge (Fig. 2). Also associated with the master fault along the shelf's edge are northeast trending and northwest trending normal faults. Such structures in echelon arrangement are typical of shear (Sylvester, 1988) with their orientation indicating that the fault along the shelf's edge is right- lateral. Motion along the shelf's edge fault includes vertical motion leading to the formation of the $32-157 \mathrm{~m}$ high upper slope with a vertical gradient as high as $14^{\circ}$ and the slumps along the base of the slope at $3^{\circ} 08^{\prime} \mathrm{W}$ and $3^{\circ} 06^{\prime} \mathrm{W}$ (Fig. 13).

\subsubsection{North of east}

The scarps along the sides of the Alboran Channel and the Alboran Ridge represent north of east faults (Figs. 2-5). Bourgois et al. (1992) and Campos et al. (1992) suggested that the scarps on the sides of the Alboran Ridge were transpressive right-lateral strike-slip faults and that they were associated with the uplift of the ridge. In contrast, Maldonado et al. (1992) and Woodside and Maldonado (1992) inferred that the fault along the northwest side of the Alboran Ridge is left-lateral and may be an offshore extension of the left-lateral Jebha Fault separating the External and Internal Riftian Systems in the Rif Cordillera in northern Morocco. They further speculated that the fault along the northwest side of the Alboran Ridge was connected to the southern end of the SerrataCarboneras Fault via east of north trending left-lateral fault near $2^{\circ} 45^{\prime} \mathrm{W}$. Our multi-beam data may support such a link. The Serrata-Carboneras Fault appears to terminate against a northwest trending fault system and south of this fault is another left-lateral fault that merges with the 

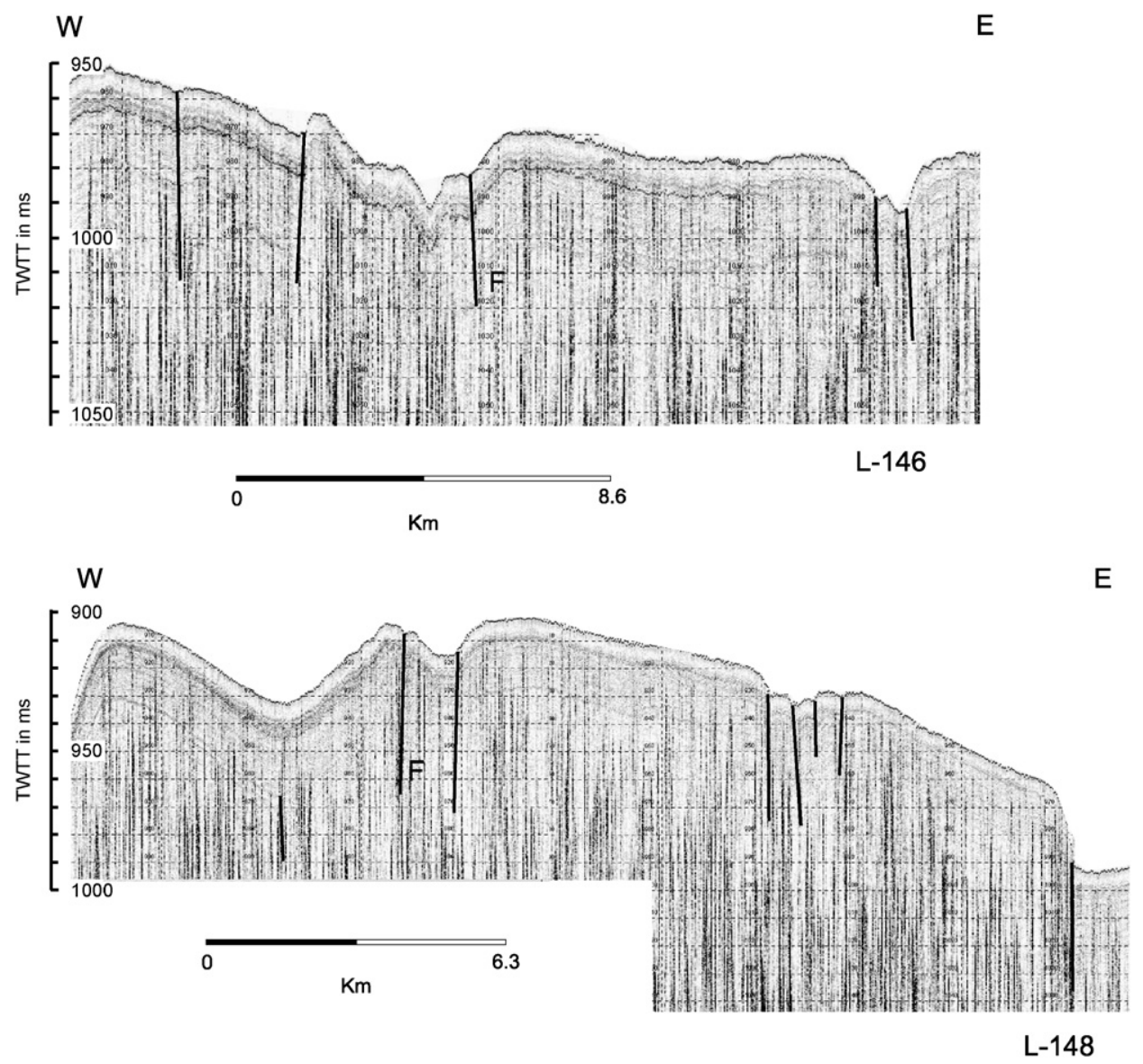

Fig. 11. TOPAS seismic reflection profiles 146 and 148. F = faults. See Fig. 12 for locations of profiles.

northwest scarp of the Alboran Ridge (Fig. 5). Woodside and Maldonado (1992) also suggested that motion along the transpressional left-lateral fault on the northwest side of the Alboran Ridge has been active since late Miocene. They and Campos et al. (1992) concluded that motion along a north-northwest dipping plane resulted in an uplift of $750 \mathrm{~m}$ of the Alboran Ridge with respect to the Alboran Channel.

Morel and Meghraoui (1996) proposed that the sides of the Alboran ridge are related to thrust faults with the southeastern one coinciding with the inland left-lateral Jebha Fault. In contrast, Bourgois et al. (1992) supposed that the fault on the southeast of the Alboran Ridge is not connected with Jebha Fault in northern Morocco, but instead appears to be connected with a mud diapir zone in the West Alboran Sub-Basin. As proposed by them the Alboran Ridge scarps are right-lateral faults and the mud diapiric west Alboran Sub-Basin basin is a pull-apart or mega-tension gash. In contrast, Comas et al. (1992) suggested that the Alboran Ridge is bound by extensional faults and that the ridge represents a horst. Watts et al. (1993, Fig. 12) found no evidence of compression in a multi-channel seismic line crossing the northwest scarp of the Alboran Ridge in the vicinity of Alboran Island. According to Watts et al. (1993) the seismic reflection pattern displayed by this line could be explained by normal faulting with the downthrown on the northwest side.

Woodside and Maldonado (1992) also speculated that at least one active right-lateral fault cuts the Alboran Ridge in a west-northwest-east-southeast direction. The multibeam data does image a northwest trending an embayment on the northwest side of the Alboran Ridge near $3^{\circ} 10^{\prime} \mathrm{W}$ (Fig. 14). This embayment with dimension of $40 \times 40 \mathrm{~km}$ extends to the axis of the Alboran Ridge. Our multi-beam data indicates that a network of widely spaced fractures trending northwest, northeast and east-west disrupts the sediments in the embayment. We infer that this fracture network is the consequence of collapse of the sediment apron triggered by motion along the northwest trending fault cutting across the Alboran Ridge described by Woodside and Maldonado (1992).

Our multi-beam data (Fig. 14) indicate that the creation of the ridge is more complex than previously proposed. These data suggest that the wide area of the ridge east of $3^{\circ} 05^{\prime} \mathrm{W}$ is a volcanic structure and that this volcanic edifice becomes larger northeastward. This increase in size suggests that igneous activity propagated northeastward along fractures to at least $35^{\circ} 40^{\prime} \mathrm{N}$. West of $3^{\circ} 05^{\prime} \mathrm{W}$ the Alboran Ridge consists of a narrow igneous ridge mantled by sediments on its northwest side dipping way from the high. Part of this sediment blanket has been displaced 


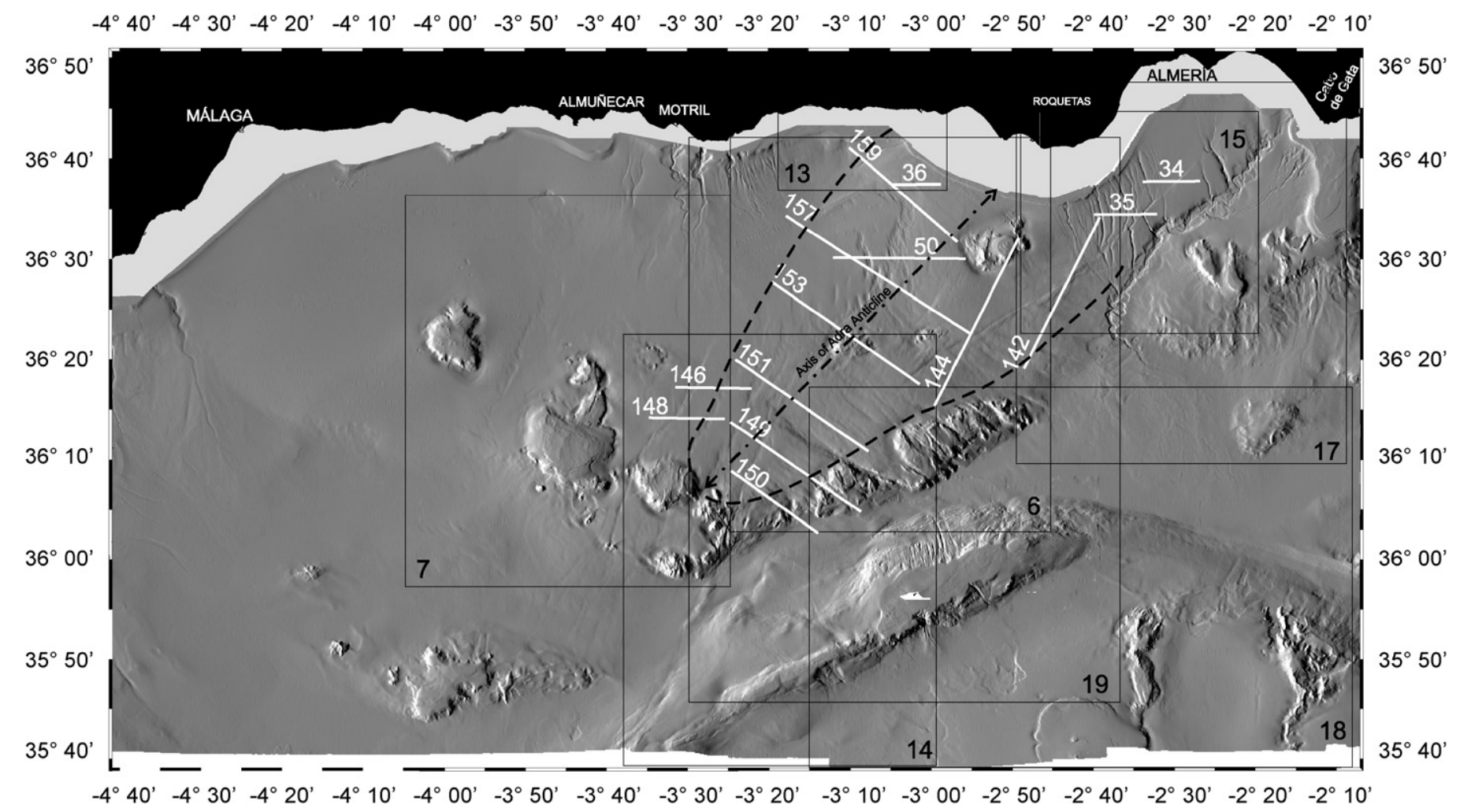

Fig. 12. Shaded relief map of Alboran Basin showing locations of TOPAS profiles in Figs. 8-11 and 16 and shaded relief map blowups in Figs. 6, 7, 13-15, $17-19$.

northward creating the broad embayment at $3^{\circ} 10^{\prime} \mathrm{W}$. Thus, the evolution of the Alboran Ridge involves volcanic construction at its northeast end along one or more northeast trending fractures and propagation of igneous activity along fracture zones and partial burial of the igneous features. This was followed by a period of compression and uplift of the ridge along a right-lateral on the southeast side of the ridge and a left-lateral on the northwest side of the ridge west of $3^{\circ} 15^{\prime} \mathrm{W}$.

\subsubsection{Northeast faults}

A northeast trending left-lateral fault cuts across the western end of the $36^{\circ} 10^{\prime} \mathrm{N}$ High and the Alboran Channel merging with the scarp along the northwest side of the Alboran Ridge near $3^{\circ} 30^{\prime} \mathrm{W}$ (Figs. 2, 5 and 14). It is at this junction that the sediments onlapping the northwest flank of the Alboran Ridge display evidence of compression (Figs. 3, 4, 5, 14; Campos et al., 1992). This fault crosses obliquely across the $36^{\circ} 10^{\prime} \mathrm{N}$ High east of Djibouti Bank apparently terminating on a northwest right-lateral fault (Fig. 5). The northeast trending Serrata-Carboneras left-lateral fault, north of the right-lateral fault, may be a possible northeast extension of this fault. A northeast left-lateral fault, fragmented by northwest trending right-lateral faults, also occurs on the basin apron west of the Adra Anticline (Fig. 13).

Other examples of northeast trending left-lateral faults are the Palomares and the Serrata-Carboneras faults (Figs. 5). North of $37^{\circ} 10^{\prime} \mathrm{N}$ the Palomares Fault is aligned with the coast north of Cabo de Gata and from $37^{\circ} 10^{\prime} \mathrm{N}$ to $36^{\circ} 50^{\prime} \mathrm{N}$ is represented by a subsurface east facing scarp beneath the mid-shelf (Medialdea Vega et al., 1982). From $36^{\circ} 50^{\prime} \mathrm{N}$ to $36^{\circ} 32^{\prime} \mathrm{N}$ the Palomares Fault is along the east side of the platform off Cabo de Gata. South of the platform the fault trace is unmapable as there is no topographic feature on the Alboran Basin slope that could be attributed to any structural dislocation associated with this fault.

On land the Serrata-Carboneras left-lateral fault along the west side of Sierra de Gata, a Neogene volcanic high, has a length of $50 \mathrm{~km}$, a width of $15 \mathrm{~km}$ and has displacement of 25-40 km (Montenet et al., 1987; Keller et al., 1995; Rodríguez-Fernández et al., 1999, 2000; Faulkner et al., 2003). Northeastward the fault terminates against the north-northeast trending left-lateral Palomares Fault. It was lateral motion along the Serrata-Carboneras Fault that supposedly transported the Neogene Cabo de Gata volcanic block northeastward and brought it in contact with Neogene intramontane basin sediments and the Alboran Domain rocks (Hoernle et al., 2003). Bell et al. (1997) stated that motion along the Serrata-Carboneras Fault during the last $100 \mathrm{ka}$ has been one of uplift, not lateral motion, and that this uplift has been in the order of 0.05-0.1 mm/year. Rodríguez-Fernández et al. (2000) inferred that from the Messinian to late Pliocene the Serrata-Carboneras Fault Zone on land bound a subsiding trough and that this trough was deformed in the Pliocene to form the Serrata horst, a volcanic high, rising $350 \mathrm{~m}$ 


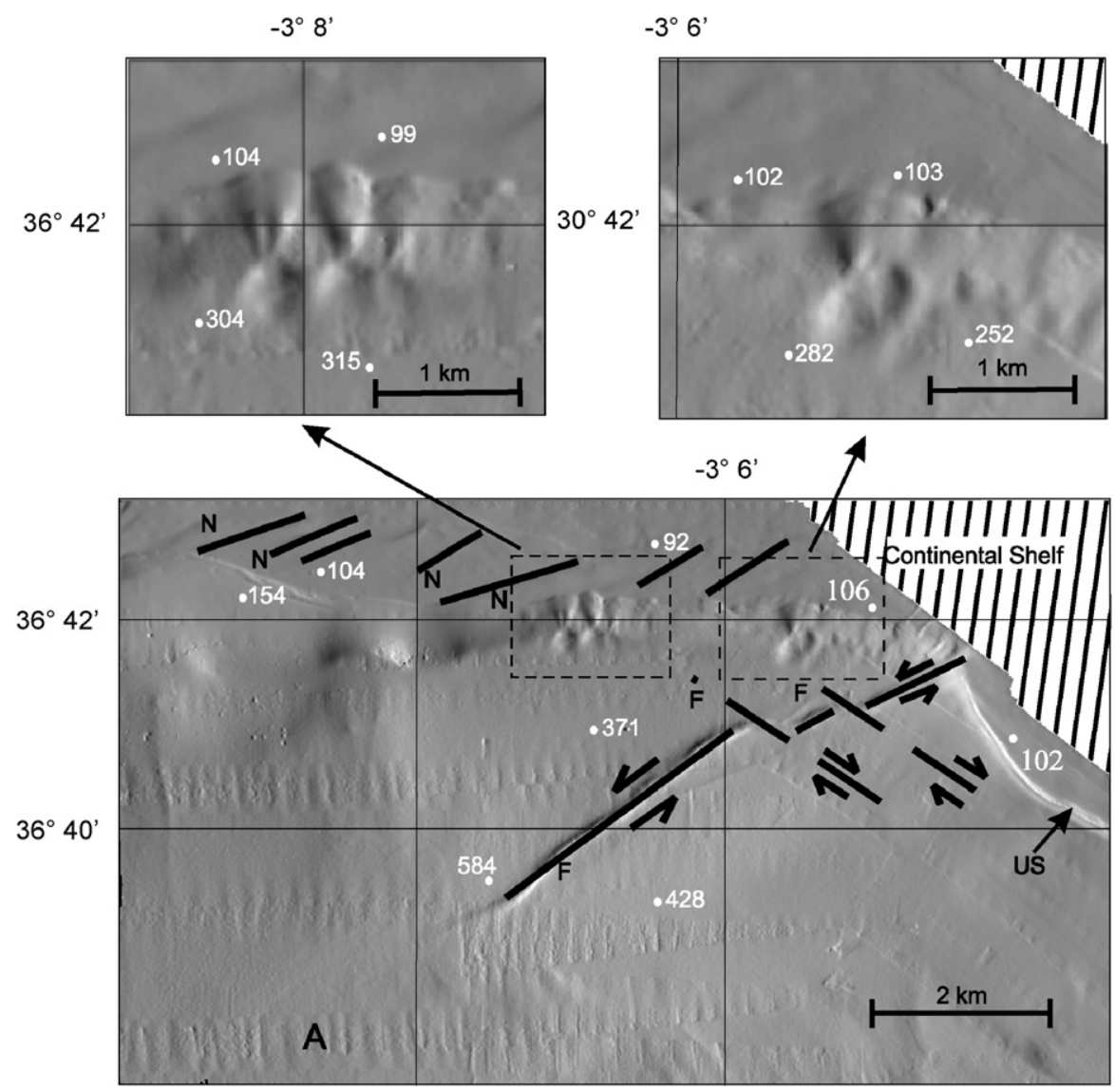

Fig. 13. Northeast trending faults on the lower basin slope and basin apron cut by two northwest trending left-lateral faults. A narrow northeast trending notch represents the fault on the outer shelf. Note slumps (insets) on the upper slope northwest of fault. This mass wasting is probably the result of motion along the fault parallel to the shelf's edge. $\mathrm{A}=\operatorname{artefact} ; \mathrm{F}=$ transcurrent faults; $\mathrm{N}=$ normal faults; US = upper slope. Arabic numbers are water depth in meters.

above sea level. Movement along the branch of the fault northwest of the Serrata horst has led to $100-115 \mathrm{~m}$ left-lateral displacement and formation of pressure ridges cored with Pliocene sediments (Boorsma, 1992). The fault branch southeast of the Serrata block becomes obscured and is replaced by a set of parallel penetrative faults that Boorsma (1992) interpreted as Y shears or shears with an orientation between Riedel and Y shears. Associated with these faults is the steeping of the sediment strata that Boorsma (1992) stated that their inclination is opposite to the drag expected on the fault from a vertical component of the oblique-slip dislocation. He proposed that the structural features are the result of severe brittle strain at the surface that accommodated the sinistral transcurrent motion of the Serrata-Carboneras Fault.

The fault branches on either side of the Serrata block are represented offshore in the Gulf of Almería by two parallel northeast trending faults (Fig. 5; Baena et al., 1977). The northwest fault, Fault A, is still active and can be traced on land, whereas the fault southeast of A, Fault B, is inactive and its landward extension is partly buried by Quaternary sediments. Basement along Fault $\mathrm{A}$ is downthrown on the northwest of the Serrata-Carboneras Fault Zone and that the zone is mantled by Messinian sediments with the
Pliocene to Holocene sediments sealing the fault being deformed (Rodríguez-Fernández and Martín-Penela, 1993). As faulting effects the sea floor it is a clear indication that Fault $\mathrm{A}$ is active. North of $36^{\circ} 30^{\prime} \mathrm{N}$ the Serrata-Carboneras Fault offshore extension is represented offshore by a groove between two scarps (Profiles 1, 4, 5, 7 and 8, Fig. 15). Along Profiles 2, 3 and 7 this grove is subdued indicating that the relief of the fault trace varies along the strike. At the southwest end of the fault, the trace is characterized by two subdued grooves (Faults A and B) separated by a low relief high (Profiles 10 and 11, Fig. 15). This high, which dominates most of the fault trace south of $36^{\circ} 30^{\prime} \mathrm{N}$, is too large to be a pressure ridge as such structures tend to be in the order of centimeters to tens of meters long and a few centimeters to a few meters wide (Tchalenko and Ambraseys, 1970). It is probably a low relief fault-bounded uplifted block (horst) associated with such pressure ridges. This high, which is aligned parallel to the fault trace, is comparable to the several hundred meters high and about $10 \mathrm{~km}$ long Serrata block on the fault segment above sea level. Just south of $36^{\circ} 30^{\prime} \mathrm{N}$ and east of $2^{\circ} 40^{\prime} \mathrm{W}$ the offshore fault segment of the Serrata-Carboneras Fault is displaced southward about $1-2 \mathrm{~km}$ and east of $2^{\circ} 50^{\prime} \mathrm{W}$ is displaced to the northeast. At its southern end 


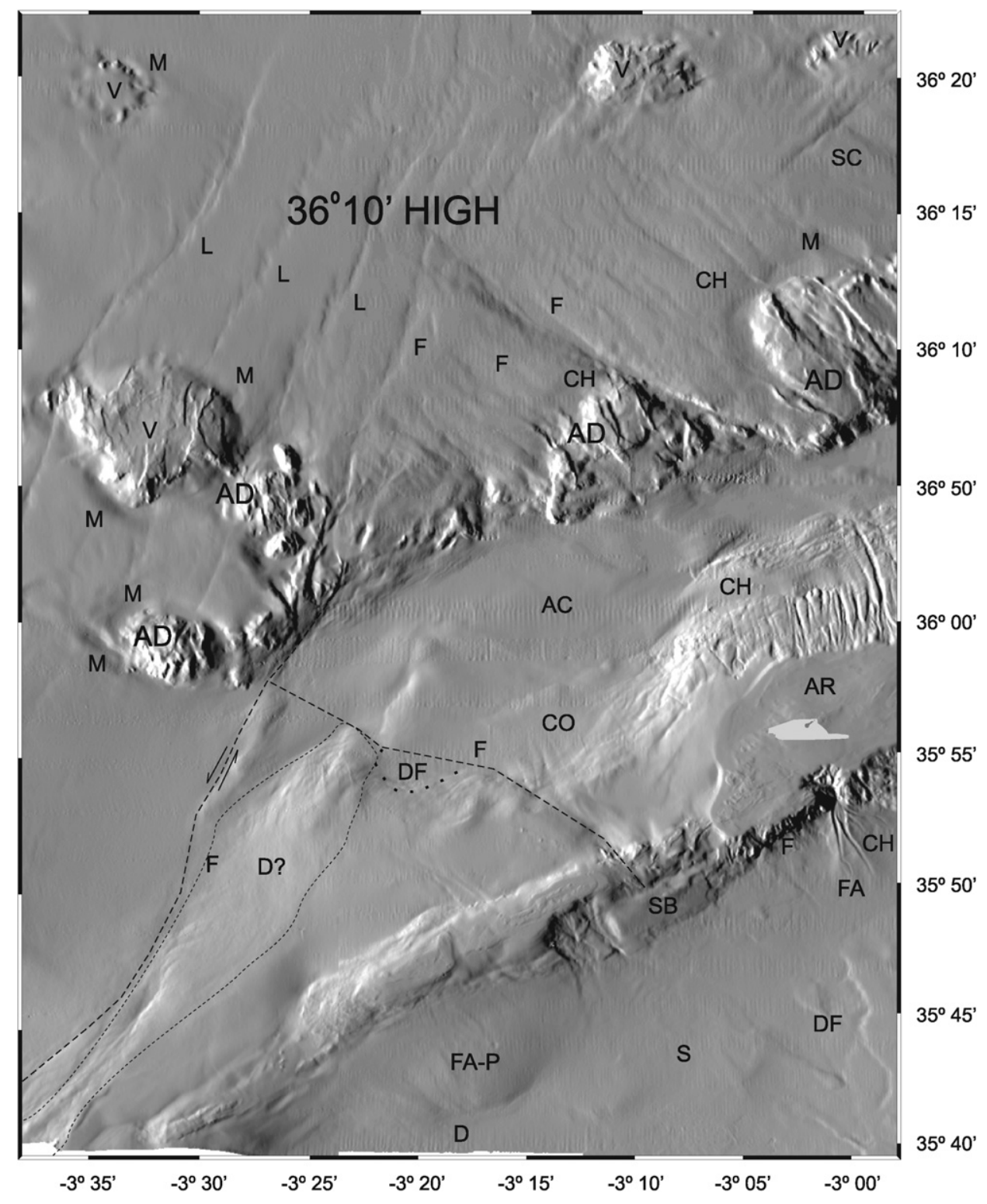

Fig. 14. Shaded relief map of an embayment on the northwest side of the Alboran Ridge. We infer that this feature is due to massive collapse of the sediments onlapping the Alboran Ridge volcanic core. $\mathrm{AC}=$ Alboran Channel; $\mathrm{AD}=$ Alboran Domain; $\mathrm{AR}=\mathrm{Alboran} \mathrm{Ridge}$; $\mathrm{CH}=$ channels; $\mathrm{CO}=$ collapse structure; $\mathrm{D}=$ deformed; $\mathrm{DF}=$ debris flow; $\mathrm{F}=$ fault; $\mathrm{FA}=$ fan; $\mathrm{H}=36^{\circ} 10^{\prime} \mathrm{N}$ High; $\mathrm{L}=$ fractures with depressions; $\mathrm{M}=\mathrm{Moat}$ created by bottom current erosion; S = South Alboran Sub-Basin; $\mathrm{SB}=$ slump block; SC $=$ Serrata-Carboneras Fault, V = volcanic seamounts. Note depressions along lineations (fractures) on the $36^{\circ} 10^{\prime} \mathrm{N}$ High. See Fig. 12 for location of diagram.

the fault turns to the southwest. From $36^{\circ} 28^{\prime} \mathrm{N}$ to $36^{\circ} 24^{\prime} \mathrm{N}$ the fault displays what Christie-Blick and Biddle (1985) call horse splays. These features may be related to a slight change in the trend of the fault at $36^{\circ} 30^{\prime} \mathrm{N}$.

Hoernle et al. (2003) reported that in their PARASOUND investigation of the fault zone they encountered several fault strands some of which are associated with faults, folds and onlap patterns. They further concluded that since faulting propagates to the sea floor faulting must be very recent. In our TOPAS profiles, two of which are displayed in Fig. 16, the northeast end of the fault trace is an asymmetrical groove bordered on the east by a west facing scarp (Line 34). This scarp appears to be the side of a ridge with a rounded crest and a gentler sloping side on its east. Seismic reflection profiles acquired with a system more powerful than the TOPAS system indicates that the sinistral Serrata-Carboneras Fault system is several $\mathrm{km}$ wide displaying negative flower structure patterns with down faulted blocks northwest of the fault trace (Rodríguez-Fernández and Martín-Penela, 1993). The fault system affects basement, the faults branch upward and become simpler with depth and in transverse sections the faults display normal and inverse displacements for the same reflector.

The tributaries draining onto Almería Canyon from the northwest display right-lateral offsets as they cross the 

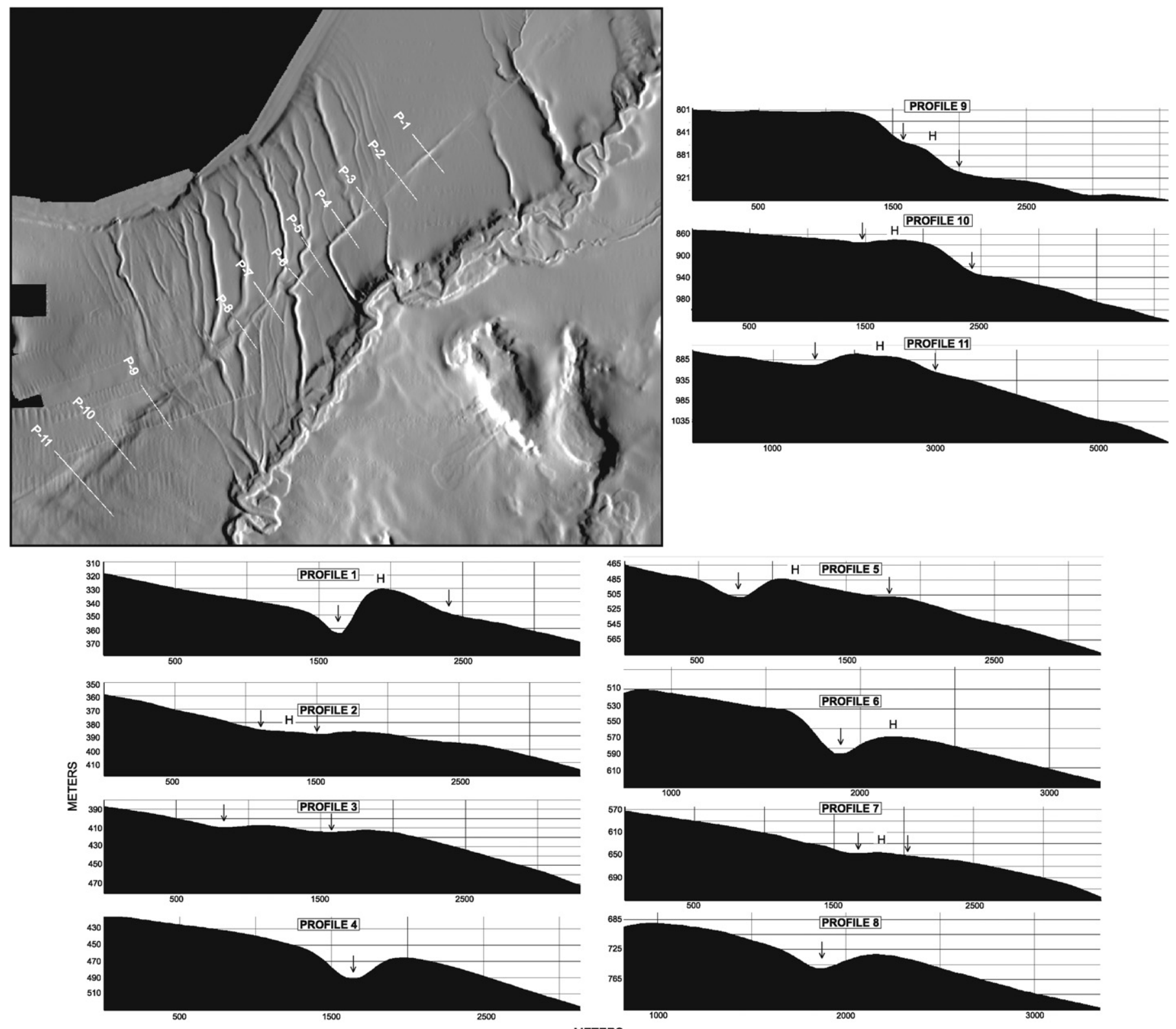

Fig. 15. Cross-sections of Serrata-Carboneras Fault. Arrows = fault traces; $\mathrm{H}=$ faulted block parallel to fault traces. Profiles compiled from multi-beam bathymetric data.

Serrata-Carboneras, offsets ranging from $<1 \mathrm{~km}$ to nearly $3 \mathrm{~km}$ (Fig. 17). Other channels crossing the fault trace show no displacement. We infer from this that this displacement is not structurally controlled as if did it meant that the Serrata-Carboneras changes from left-lateral onshore to right-lateral offshore. We speculate that the channels entering the fault trace flowed southwestward along the fault trace before returning to their original orientation of flow in the manner of deflected streams (Keller and Pinter, 2002). Thus, they are not offset channels indicating the direction of relative displacement along the fault, but deflected ones.

It has been proposed that the geometry of the Almería Canyon, southeast of the Serrata-Carboneras Fault Zone, is in part controlled by north-northwest and northeast faults (Cronin, 1994, 2000; Cronin et al., 1995). Such a systems of secondary faults, oversteps, branching and braiding, are fundamental features of strike-slip fault zones and fault systems (Christie-Blick and Biddle, 1985). Possibly the faults controlling the geometry of Almeria Canyon are the creation of the rotation of small blocks trapped between the Serrata-Carboneras and a fault along the basin slope south of Cabo de Gata. Interaction between these blocks produced segments of convergence and divergence. Such interplay between faults is not unrealistic as theoretical studies indicate that strike-slip faults separated by less than twice the depth of faulting display considerable interaction (Christie-Blick and Biddle, 1985). 

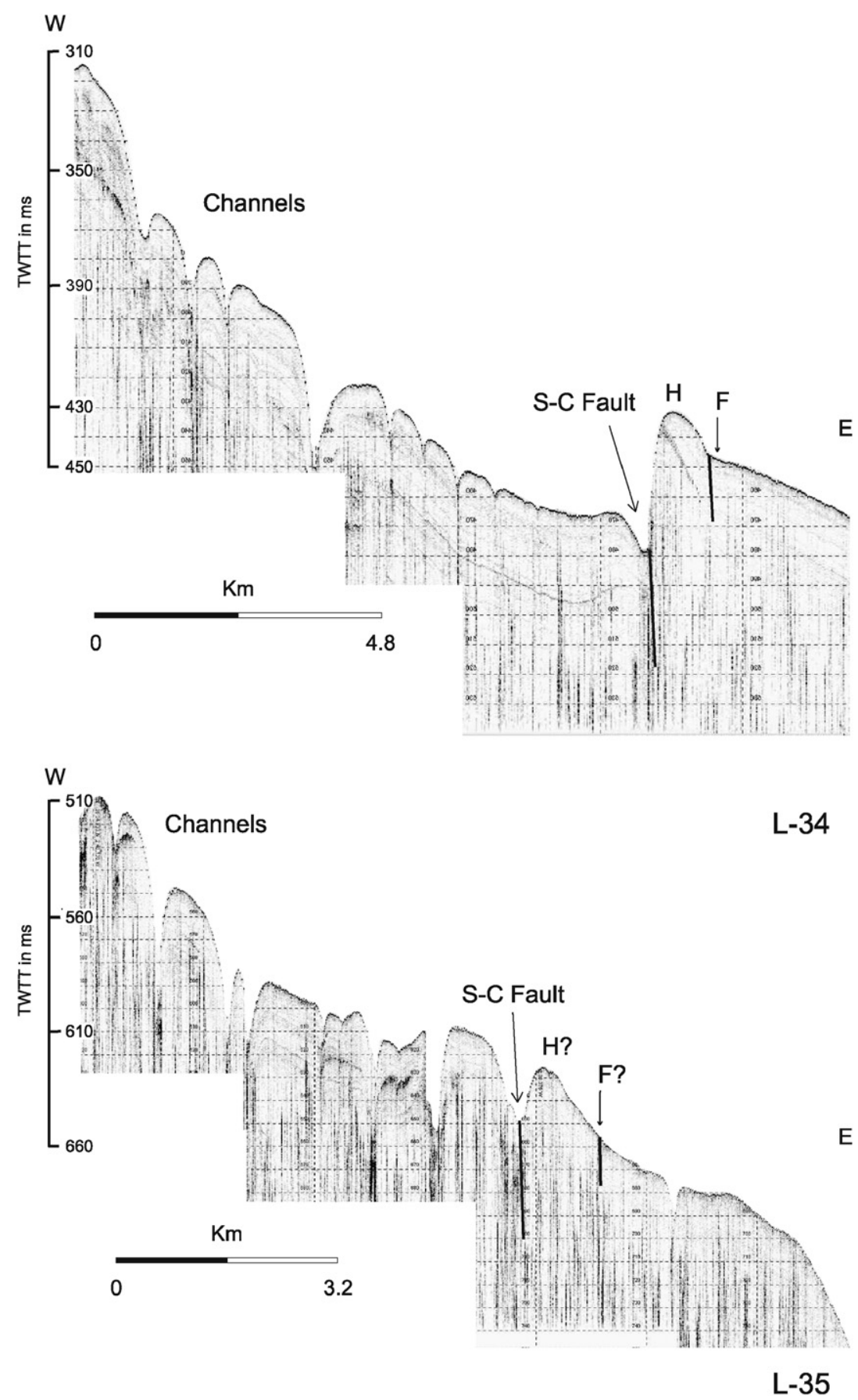

Fig. 16. TOPAS profiles 35 and 34 of the Serrata-Carboneras Fault. See Fig. 12 for locations of profiles. Along Line 34 an asymmetrical notch flanked on the east by west facing scarp characterizes the fault. In contrast, on Line 35 the fault a symmetrical V-shaped notch represent is traced. F, F? = fault trace; $\mathrm{H}, \mathrm{H}$ ? = horst. Differences in fault morphology are a consequence of recent submarine erosion along the fault trace on 35 .

Buforn et al. (1995) have proposed that the Palomares and Serrata-Carboneras faults extend across the Alboran Basin and joined with Agadir-Nekor fault in North Africa. López-Ruiz et al. (2002) inferred that the Palomares and the Serrata-Carboneras Faults are parts of a mega-fault, the Trans-Moroccan, Western Mediterranean-European sinistral fault, extending from northern Morocco, through the Alboran Basin, eastern Iberia, Valencia Trough and
Lyon Basin, across France and Germany to a NNW extensional zone in northern Europe and North Sea. This mega shear supposedly is due to an increase in the convergence of Africa and Eurasia from latest Miocene to the present. As this north-south compression became more prominent it led to the creation of the mega shear extending from Morocco to northern Europe that flanks a west-directed escaping western Mediterranean block on its 


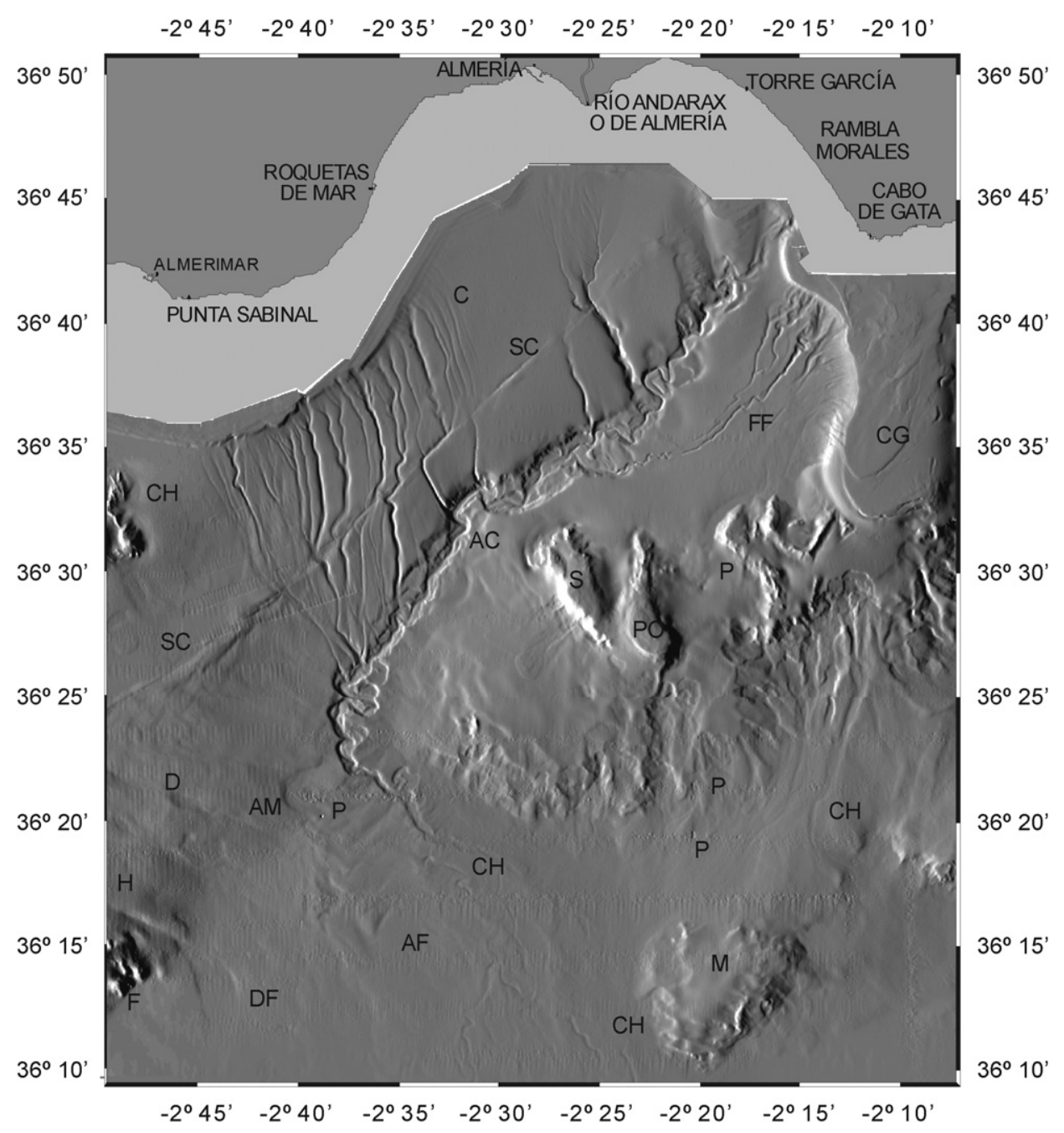

Fig. 17. Shaded relief diagram in the vicinity of Almería Canyon. $\mathrm{AC}=$ Almería Canyon; $\mathrm{AM}=\mathrm{Abandoned}$ meander; $\mathrm{AF}=\mathrm{Almería} F \mathrm{Fan} ; \mathrm{C}=\mathrm{Campo}$ de Dalias canyon system; tributaries to Almeria Canyon; $\mathrm{CH}=$ channels; $\mathrm{CG}=$ Cabo de Gata Bank; $\mathrm{D}=$ depression; $\mathrm{DF}=$ debris flow; $\mathrm{P}=$ pockmarks; $\mathrm{F}=$ fault; $\mathrm{H}=36^{\circ} 10^{\prime} \mathrm{N}$ High; $\mathrm{M}=$ Maimonides Seamount; $\mathrm{P}=$ pockmarks; $\mathrm{PO}=$ Pollux Bank; $\mathrm{S}=$ Sabinar Bank; SC $=$ Serrata-Carboneras Fault. Note meandering channels $(\mathrm{CH})$ in Almería Fan. See Fig. 12 for location of diagram.

east (López-Ruiz et al., 2002). At present, however, is not continuous, but is disrupted by dislocation along the northwest right-lateral fault extending from the Habibas Escarpment to the shelf's edge east of Malaga (Fig. 5).

\subsubsection{Northwest trends: faults and features created by sedimentary processes}

A northwest trending right-lateral fault extends from the Habibas Escarpment (Yussuf Fault) across the Alboran Ridge and Alboran Channel to the southern edge of the $36^{\circ} 10^{\prime} \mathrm{N}$ High (Fig. 5). We speculate that this fault may extend across the high and the Alboran Basin apron and slope to join one of the northwest trending faults displacing the shelf's edge (Fig. 5). The two normal faults described by Watts et al. (1993) from the Alboran Channel may be part of this right-lateral northwest trending fault system. Mauffret et al. (1987) interpreted the depression between the Yusuf Ridge and the Habibas Escarpment (Figs. 4, 5 and 18) as a pull apart basin between two overlapping northwest trending right-lateral strike-slip faults. Although this basin resembles the Elat Trough in the Gulf of Aqaba and the Ridge Basin along the San Andreas Fault it differs from them morphologically (Watts et al., 1993). The basin at the base of the Habibas is symmetrical in cross-section, whereas those in Elat Trough are asymmetrical reflecting the varying vertical displacement along the two faults. Hoernle et al. (2003) also stated that PARASOUND recording across this basin indicate that the basin is sediment filled, that the northern margin of the basin is characterized by onlap indicating fault activity, and that basin's southern margin appears to be inactive.

Another northwest trending right-lateral fault cutting across the Alboran Channel is associated with the embayment along the northwest flank of the Alboran Ridge. Woodside and Maldonado (1992) speculated this fault cuts across the ridge; possibly a low on the ridge near $3^{\circ} 10^{\prime} \mathrm{W}$ defines this cross-cutting shear. Other northwest trending right-lateral faults are present northwest of Chella 


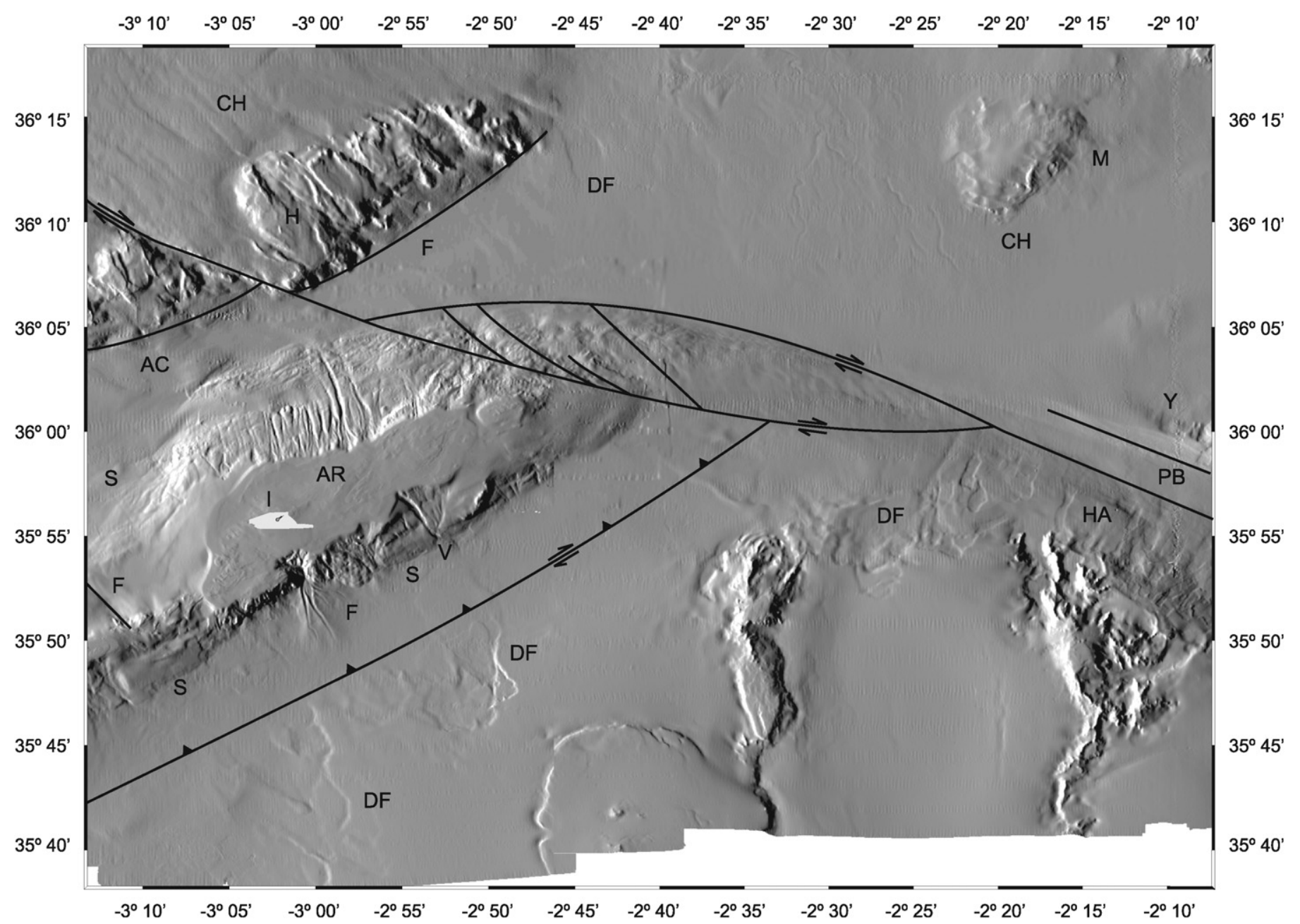

Fig. 18. Shaded relief diagram of the eastern ends of the Alboran Channel and Alboran Ridge showing the pull-apart basin between Yusuf Ridge (Y) and Habibas escarpment (HA). AC $=$ Alboran Channel; $\mathrm{AR}=$ Alboran Ridge; $\mathrm{CH}=$ channels; $\mathrm{DF}=$ debris flow; $\mathrm{F}=\mathrm{fault} ; \mathrm{FA}=\mathrm{fan} \mathrm{H}^{\mathrm{a}}=36^{\circ} 10^{\prime} \mathrm{N}$ High; $\mathrm{I}=$ Alboran Island; $\mathrm{M}=$ Maimonides Seamount; $\mathrm{PB}=$ pull-apart basin; $\mathrm{S}=$ slumps see Fig. 12 for location of diagram.

Bank and along the northwest trend of Algarrobo-Djibouti Seamount chain. If these volcanic edifices were constructed by igneous extrusions along such a fault trace, then this structure is much older than the faults propagating to the sea floor. Other examples of northwest trending faults in the Alboran Basin are the faults displacing the fault along the shelf's edge.

Another system of northwest trending lineation straddle the northwest trending right-lateral fault extending across the Alboran Basin (Fig. 5) (Profiles 142, 144, 149-151, 153, Figs. 7, 8, 19, 20). This network consists of steep-sided elongate to ellipsoid shaped parallel channels $9-20 \mathrm{~km}$ long, $<1-1 \mathrm{~km}$ wide and several tens of meters deep whose topographic continuity is disrupted by one circular depression that probably represent a pockmark formed by the expulsion of gas (Figs. 6, 14, 19). The features southeast of the Serrata-Carboneras Fault extend to the base of the slope descending to the East Alboran sub-basin (Fig. 19). The channels southwestward of the SerrataCarboneras Fault extend northwestward to crest of the Adra Anticline terminating against the chain of northeast trending linear depressions. Southeastward these features are linked to northwest trending lows cutting across a ridge along the southeast edge of the $36^{\circ} 10^{\prime} \mathrm{N}$ High where rocks of the Alboran Domain are exposed. Further west the channels are entrained with a triangular shaped terrain whose boundaries consist of the right-lateral fault displaying horse splays toward the northwest, a ridge of Alboran Domain and northeast trending fracture whose axis consists of a series of narrow depressions and is displaced in a right-lateral sense by the fault (Fig. 19). The channels parallel the fault and terminate against the fracture. There is no evidence of channelling northwest of the fracture suggesting that the fractures are younger than the channels. We infer that this lineation are not of structural origin as they are parallel the northwest trending strike-slip fault and are oriented nearly at right angles to the northeast trending strike-slip faults. We infer that they were created by submarine sedimentary processes. Their dimensions and orientation oblique to the supposed westerly flowing Mediterranean tend us to eliminate the possibility that they represent furrows (1-150 $\mathrm{m}$ wide, $0.5-350 \mathrm{~m}$ deep and 


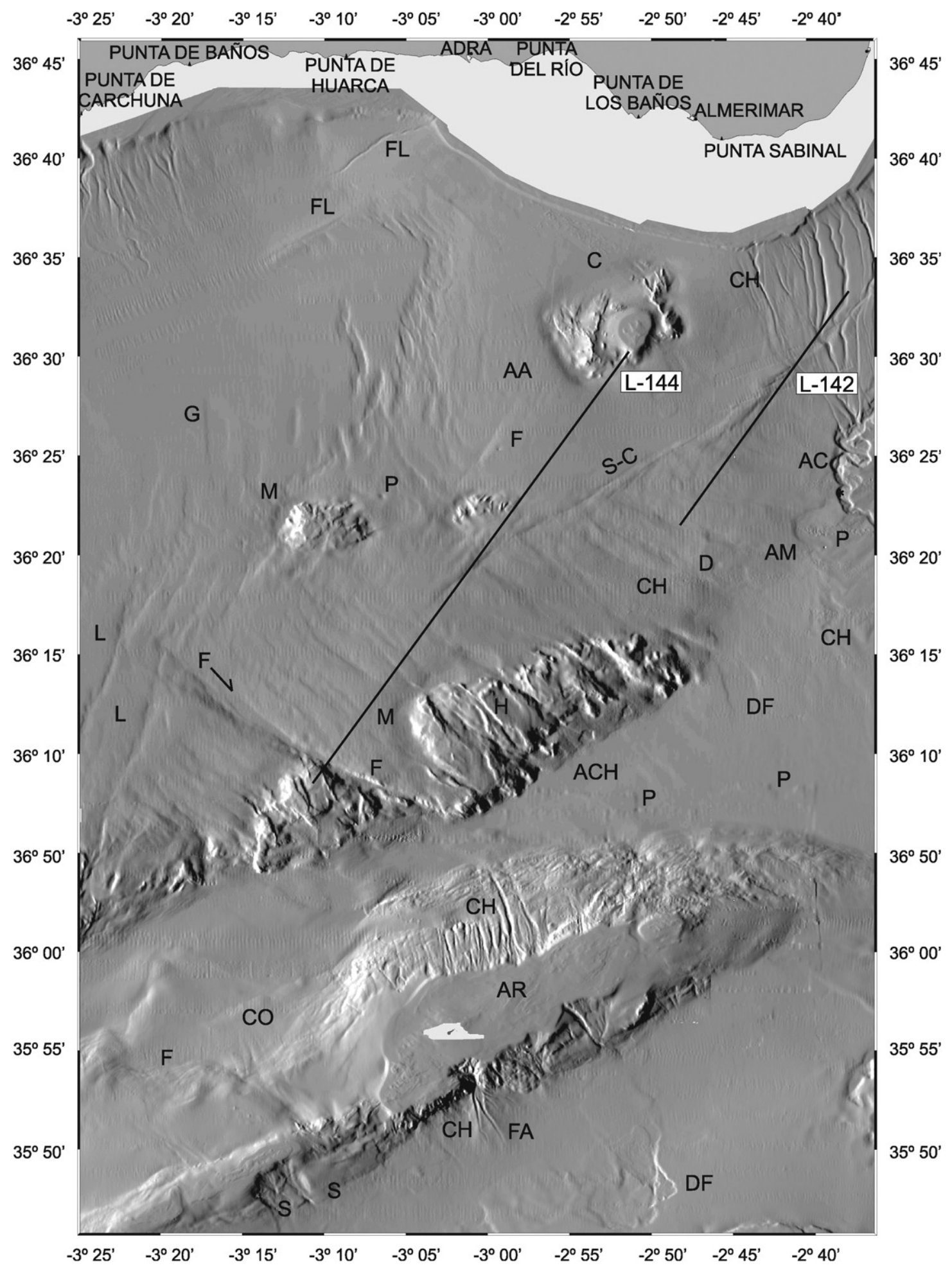

Fig. 19. Shaded relief diagram of the northwest striking faulted-folded terrain southeast and southwest of the Serrata-Carboneras Fault showing the locations of the TOPAS profiles in Fig. 20. See Fig. 12 for location of diagram. AA = Adra Anticline; AC = Almería Canyon/Channel; ACH = Alboran Channel; $\mathrm{AM}=$ Abandoned Meander; $\mathrm{AR}=$ Alboran Ridge; $\mathrm{C}=$ Chella Bank; $\mathrm{CH}=$ channels; $\mathrm{CO}=$ collapse structure; $\mathrm{D}=$ depression; megapockmark; $\mathrm{DF}=$ debris flow; $\mathrm{F}=$ faults; $\mathrm{FA}=$ fan; $\mathrm{G}=$ Graben; $\mathrm{L}=$ fractures with depressions; $\mathrm{M}=$ moat eroded by bottom currents; $\mathrm{S}=$ slump; $\mathrm{S}-\mathrm{C}=$ Serrata-Carboneras Fault.

hundreds of meter long; see Flood, 1983) formed by bottom currents. We propose that they were formed turbidity currents or sheet debris flows that originated along the southeast flank of the Adra Anticline. Those cutting across the Alboran Domain along the southeast edge of the $36^{\circ} 10^{\prime} \mathrm{N}$ probably were created by headward erosion and probably represent superposed channels that acquired their courses on sediments resting on the Alboran 


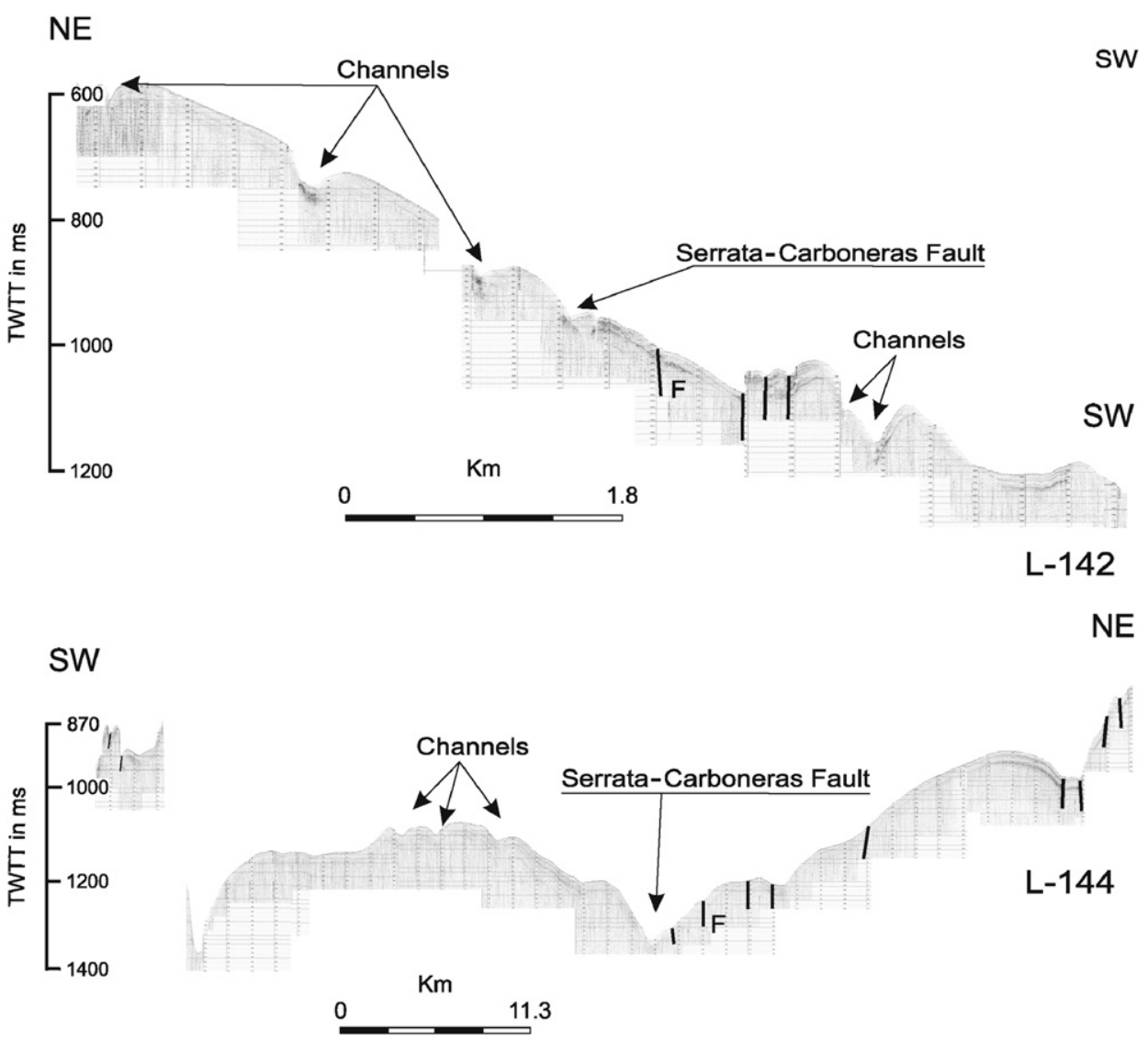

Fig. 20. TOPAS profiles 142 and 144 of the Serrata-Carboneras Fault. See Fig. 19 for locations of profiles.

Domain. The channels later cut through the sediments and transected the buried Alboran Domain acquiring their courses independent of the structure of the Alboran Domain.

\section{Pockmarks and mounds}

Pockmarks, circular to ellipsoidal craters, with tens of meters diameter and reliefs of less than $5 \mathrm{~m}$, of unknown origin are found at several sites in the Alboran Basin. We have discovered them on the basin slope off Cabo de Gata and at the apex of Almería Fan (Figs. 5, 6, 17, 19), the western edges of the Alboran Channel and the $36^{\circ} 10^{\prime} \mathrm{N}$ High, in the center of the high, northwest of North Herradura Bank and in the vicinity of Algarrobo Bank. A pockmark was also imaged along the trace of one of the northeast trending fractures in the $36^{\circ} 10^{\prime} \mathrm{N}$ High. If the pockmarks are the creation of the seepage of gas and interstitial fluids from the underlying bedrock along the fracture zones, then gas/fluid venting must be a significant factor in the formation the tectonic style of the Alboran Basin.

At the base of the northern slope are three fields of mounds, two east of Malaga at a depth of 225-250 m and one southeast of Campo de Dalías at a depth of 150-225 m. The mounds have reliefs of $1-9 \mathrm{~m}$ and lengths of $91-131 \mathrm{~m}$. Possibly these features were formed by deep-water coral and are comparable to the mounds along the western margin of Porcupine Bank (O'Reilly et al., 2003). The corals in the eastern North Atlantic flourished in waters 150-2000 $\mathrm{m}$ deep, at temperatures of $4-12{ }^{\circ} \mathrm{C}$, associated with strong bottom currents, grow on hard substrate and create structures having diameters of $50-850 \mathrm{~m}$ and heights of $5 \mathrm{~m}$ to as much as $200 \mathrm{~m}$. In the absence of sampling such an origin for the mounds in the Alboran Basin is geologically viable, but their location on a soft substrate easily penetrable by a low energy TOPAS seismic system led Muñoz et al. (in press) to propose that the mounds are the creation of carbonate deposition from the oxidation of methane by bacteria and that the structures are comparable to those described by Camoin et al. (1988) and Canet et al. (2003). They also suggested that the methane is of thermogenic origin and that it reached the sea floor via seeps along faults at the base of the slope.

\section{Discussion}

\subsection{Tectonic evolution}

The morphology of the Alboran Basin consisting of circular highs, linear ridges, broad mid-basin highs parallel and oblique to its axis, an oblique trending basin slope off Cabo de Gata, canyons on the basin north slope and faults 
volcanic cover. It is here that the topography suggests that deformation as a result of structural inversion led to the exhumation of the Alboran Domain along the southeast side of the $36^{\circ} 10^{\prime} \mathrm{N}$ High. It was this deformation that led to the creation of east-west, north of east, northwest and northeast faults and fractures.

\subsection{Microcontinent or orogenic float}

Distribution of sea-floor spreading magnetic anomalies west of Iberia and Africa indicate that Iberia has been moving as part of the Eurasian plate since late Oligocene (Srivastava et al., 1990). These anomalies indicate that the relative motion between Eurasia and Africa is left-lateral with Iberia moving westward relative to Africa. Whereas the Eurasian-African plate boundary from the MidAtlantic Ridge to the Straits of Gibraltar is well defined, east of the straits this boundary is not. Morel and Meghraoui (1996) inferred that episodes of compression in the Cenozoic have concealed the boundary between the Eurasian and African plates. Morel and Meghraoui (1996) stated that transpression zones along plate boundaries, such as in the Alboran Basin, could result from coeval lateral displacement (simple shear) and compression at right angles to the plate boundary (pure shear) with homogeneous and uniform strain distribution in the deformation zone. Negredo et al. (2002) state that the Alboran Basin has undergone significant transpression and that the western part of the Alboran Basin and surrounding area is being extruded WNW with respect to Iberia. All these factors indicate that the Africa-Eurasian plate boundary in the region is diffused.

Vegas et al. (1995) have proposed a model for the Alboran Basin involving the westward translation of the extra-Iberian Alboran Domain microplate between two plates and the squeezing of the microplate between the two converging plates. This has led to the overthrusting and deformation of the microplate's margins with a ramp delineating the boundary between the Variscan crust of the Iberian massif and the orogenic front of the microplate, i.e., the Betic Cordillera. However, we propose that the Alboran Domanian is not a microplate, but an orogenic float formed by continental collision margin deformation. An orogenic float is simply a terrane created by the mechanical separation of sediments and crustal units of different mechanical properties. Oldow et al. (1990) inferred that such a décollement may occur in the Alboran Basin at a deep crustal level at or near Moho, a broad zone of ductile shear. Epicenter distribution further suggests that such decoupled surfaces also occur at depths of $10 \mathrm{~km}, 20 \mathrm{~km}$ and between 30 and $40 \mathrm{~km}$ (Marín-Lechado et al., 2005). Oldow et al. (1990) also stated that the formation of such regional décollement system resulted in volume problems in continental collisions and one way of disposing the excess basement was by the formation of sub-décollement root.

Gutscher et al. (2002) postulated that Miocene compression and subsequent extension and subsidence of the orogenic floast in the Alboran Basin are due to eastward subduction beneath the Straits of Gibraltar and slab rollback toward the west. According to Vegas et al. (1995) extension of the float is due to expansion, not westward slab roll back, and that this extension terminated when no free face was available in the westward displacement of the Alboran Domain. Another possible explanation for subsidence of the orogenic float is due to the removal of the sub-décollement root by subcrustal processes, i.e., lithospheric delamination (Platt et al., 2003). After this collapse the Alboran Basin experienced inversion and coeval compression in latest Miocene as a consequence of the continued NW-SE Eurasian-African plate convergence in a NW-SE direction. We postulate that the
A

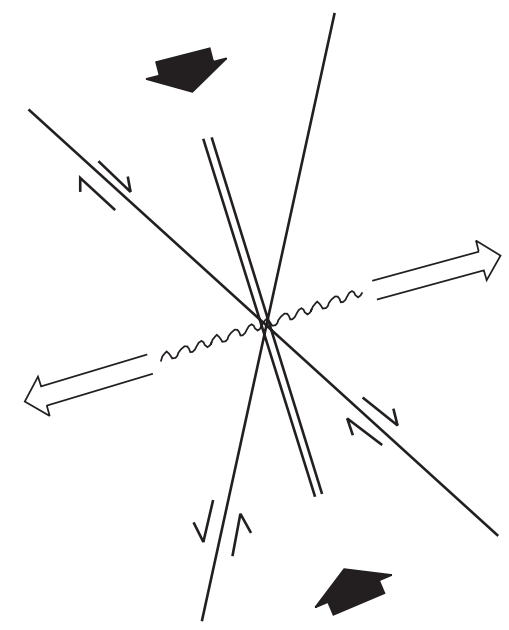

Pure shear
B

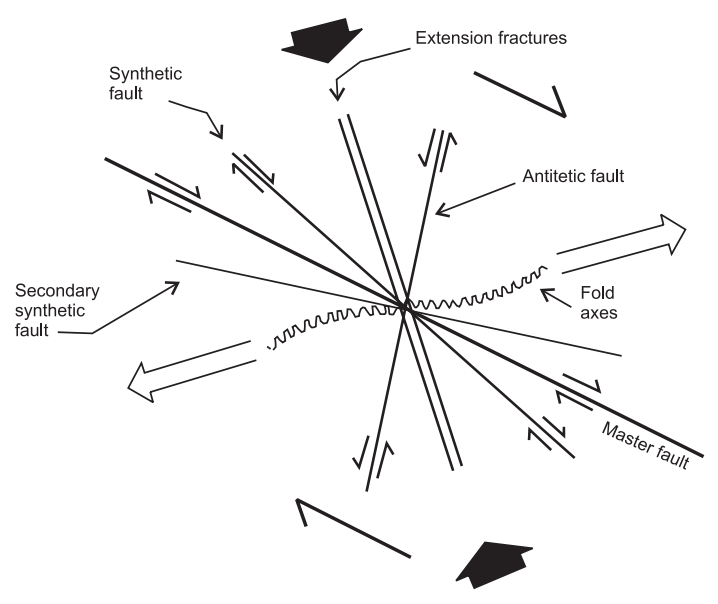

Simple shear

Fig. 22. Geometry of structures formed under a regime of pure shear (A) and simple shear (B). Modified from Sylvester (1988). 
Alboran orogenic float is being squeezed westward and is undergoing counterclock rotation as a result of this northwest-southeast convergence of the Eurasian and African plates. However, as our data is limited to multibeam based sea-floor morphology and high-resolution low penetration seismic reflection profiles we are unable to determine the validity of these various tectonic models. These data do suggest, however, that basin inversion and compression since latest Miocene was under a simple shear domain rather than a pure shear one as we explain below.

\subsection{Shear domain}

The dimensions of the shears in the orogenic float and their pronounced angle to the Alpine orogen and their crisscross pattern led Vegas (1992), Maldonado et al. (1992) and Zazo et al. (1999) to propose that the fault system in the Alboran Basin is the creation of pure shear (Fig. 22). One of the major shears of the pure shear regime in the basin is the northeast fault system (Figs. 5, 21, 22). Among this system is the northeast trending SerrataCarboneras Fault, the Palomares east of Cabo de Gata and the transpressive left-lateral fault south of the Alboran Channel aligned with the northwest slope of the Alboran Ridge at $3^{\circ} 30^{\prime} \mathrm{W}$. The fault system conjugate to the leftlateral shear is the northwest trending faults along the Habibas Escarpment (Yussuf Fault) that extends obliquely across the $36^{\circ} 10^{\prime} \mathrm{N}$ High joining one of the northwest trending right-lateral fault on the basin slope east of Malaga. Another right-lateral fault may be expressed by the northwest trend of the Algarrabo-Herradura-Djibouti banks.

We questioned the pure shear model for the origin of the Alboran Basin fault system as it does not explain the north of east right-lateral fault along the southeast side of the Alboran Ridge, the east-west right-lateral fault along the shelf's edge or the east-west right-lateral Alpujarra Fault on land (Stapel et al., 1996) and propose instead that the structures were formed under a simple shear domain. Like us, Boorsma (1992) also inferred that the SerrataCarboneras Fault system is the creation of simple-shear strike-slip deformation. Under a simple shear model the Jebha Fault, Serrata-Carboneras Fault and the Palomares Fault, could be considered antithetic faults to an east-west right-lateral mega fault (Fig. 22). In this tectonic regime the Adra and Motril anticlines and associated normal faults were the creation of compression and associated extension in the area between the left-lateral northeast trending Serrata-Carboneras Fault and the synthetic northwest trending right-lateral fault extending from Habibas Escarpment to the shelf east of Malaga. In this stress model the shelf's edge east-west trending right-lateral strike-slip faults along the shelf's edge and the Alpujarra (also known as the Gafarillos Fault; Stapel et al., 1996) Fault on land and the east of north right-lateral fault along the southeast side of the Alboran Ridge are secondary synthetic faults.
Like Vegas (1992) we also found an asymmetry in regards to the magnitude of faulting in the Alboran Basin. Whereas the eastern part of the Alboran Basin is disrupted by large strike-slip faults and associated compression, dislocations on the western part of the basin are of limited length. Vegas (1992) suggested that this difference is due to the possibility that the accommodation of the convergence of Africa and Iberia in the west is more diffused and attenuated than in the east. Another possibility is differences in the rheology of the sediments as those in the western part of the Alboran Basin include mud diapirs. For example, Fontas et al. (1985) reported that mud diapirs in the Barbados Ridge in the eastern Caribbean are restricted to thrust folds and are absent from that part of the accretionary wedge where the folds are disrupted by northwest and northeast cross-trends. Apparently, mud diapirism has affected the rheology of the sediments accounting for differences in the nature of deformation from solely thrust faulting to strike-slip failure.

\section{Conclusion}

The Alboran Basin, between Spain and Africa east of the Strait of Gibraltar, may be an orogenic float underlain by a décollement surface. It was formed as consequence of the collision of the African-Eurasian plates in the Oligocenelate Miocene. Synchronous with this compression the float experienced basin wide crustal extension and subsidence about $25 \mathrm{~m} /$ year ago. This crustal thinning was due to either convective removal of subcontinental lithosphere or lithospheric delamination. More recently the float has undergone compression due to the continuous convergence of Eurasia and Africa since latest Miocene. The fault system created in the Alboran Basin during this compressional phase is dominated by a northeast trending leftlateral strike-slip fault system, a northwest, east-west and north of east right-lateral system and a northeast zone of compression extending across the basin. They appear to be the creation of simple shear within a regime of northwest-southeast compression and northeast-southwest extension. As a consequence of this transpression the Alboran Ridge, the $36^{\circ} 10^{\prime} \mathrm{N}$ High and the northern lower slope and basin apron west of Gulf of Almería were uplifted. This uplift also influenced sedimentary processes in the Alboran Basin from canyon cutting, mass wasting on the basin slopes and the formation of pockmarks and carbonate mounds by the expulsion and oxidation of methane along faults.

\section{Acknowledgments}

We express our appreciation to the Captain and crew B/O Vizconde de Eza during the cruises 500 Viviendas, Alboran-02 and Alboran-03. Secretaría General de Pesca Marítima (SGPM) provide ship-time in the frame of "Cartas de Pesca Project". To Instituto Español de Oceanografía for technical and financial support. We also 
are indebted to T. Bolmer for a compilation of a chart of the earthquake epicenters in the Alboran Sea based on data from the National Earthquake Information Center of the United States Geological Survey. This is a contribution of Spain's ZEE program.

\section{References}

Baena, J., Fernandez Vargas, E., Garcia Rodriguez, J.J., Greene, H.G., 1977. Active faulting in coastal Almeria (SE Spain) and adjacent continental shelf. In: Seminários de Tectónica Global, Fundación Gómez Pardo, Madrid, pp. 1-16.

Bell, J.W., Amelung, F., King, G.C.P., 1997. Preliminary late Quaternary slip history of the Carboneras Fault, southeastern Spain. Journal of Geodynamics 24, 51-66.

Boorsma, L.J., 1992. Syn-tectonic sedimentation in a Neogeme strike-slip basin containing stacked Gilbert-type delta (SE Spain). Sedimentary Geology 81, 105-123.

Bourgois, J., Mauffret, A., Ammar, A., Demnati, B.A., 1992. Multichannel seismic data imaging of inversion tectonics of the Alboran Ridge (Western Mediterranean Sea). Geo-Marine Letters 12, 117-122.

Buforn, E., Sanz de Galdeano, C., Udías, A., 1995. Seismotectonics of the Ibero-Maghrebian region. Tectonophysics 248, 247-261.

Camoin, G., Bernet-Rollande, M.C., Philip, J., 1988. Rudist-coral frameworks associated with submarine volcanism in the Maastrichtian of the Pachano area (Sicily). Sedimentology 135, 123-138.

Campos, J., Maldonado, A., Campillo, A.C., 1992. Post-Messinian evolutional patterns of the Central Alboran Sea. Geo-Marine Letters 12, 173-178.

Canet, C., Prol-Ledesma, R.M., Melgareajo, J.C., Rewyes, A., 2003. Methaqne-related carbonates formed at submarine hydrothermal springs; a new setting of microbially derived carbonates. Marine Geology 199, 205-244

Christie-Blick, N., Biddle, K.T., 1985. Deformation and basin formation along strike-slips faults. In: Biddle, K.T., Christie-Blick, N. (Eds.), Strike-Slip Deformation, Basin Formation, and Sedimentation. Society of Economic Paleontologists and Mineralogists, Special Publications, vol. 37, pp. 1-34.

Comas, M.C., García-Dueñas, V., Jurado, M.J., 1992. Neogene tectonic evolution of the Alboran Sea from MCS data. Geo-Marine Letters 12, $157-164$

Comas, M.C., Dañobeitia, J.J., Álvarez-Marrón, J., Soto, J.I., 1995. Crustal reflections and structure in the Alboran basin: preliminary results of the ESCI-Alboran survey. Revista de la Sociedad Geologicade España 8, 529-542.

Comas, M.C., Platt, J.P., Soto, J.I., Watts, A.B., 1999. The origin and tectonic history of the Alboran Basin: insights from Leg 161 results. In: Zahn, C., Comas, M.C., Klaus, A. (Eds.), Proceedings of the Ocean Drilling Program, Scientific Results, vol. 161. College Station, TX, pp. $555-580$.

Cronin, B.T., 1994. Channel-fill architecture in deep-water sequences: variability, quantification and applications. Ph.D. Thesis, University of Wales, 332pp.

Cronin, B.T., 2000. The Almería Canyon and channel system, Alboran Sea, SW Mediterranean (Internet upgrade of thesis), 7pp.

Cronin, B.T., Kenyon, N.H., Woodside, J., den Bezemer, T., van der Wal, A., Millington, J., Ivanov, M.K., Limonov, A., 1995. Views of the Andarax submarine canyon: a meandering system on an active tectonic margin. In: Pickering, K.T., Hiscott, R.N., Kenyon, N.H., Ricci, R., Smith, R.D.A. (Eds.), Atlas of Deep Water EnvironmentsArchitectural Style in Turbidity Systems. Chapman \& Hall, London, pp. 84-88.

Duggen, S., Hoernle, K., ven den Bogaard, P., Harris, C., 2004. Magmatic evolution of the Alboran region: the role of subduction in the forming of the western Mediterranean and causing the Messinian salinity crisis. Earth and Planetary and Science Letters 218, 91-108.
Faulkner, D.R., Lewis, A.C., Rutter, E.H., 2003. On the internal structure and mechanics of large strike-slip fault zones: field observations of the Carboneras Fault in southeastern Spain. Tectonophysics 367, 235-251.

Flood, R.D., 1983. Classification of sedimentary furrows and a model for furrow initiation and evolution. Geological Society of America Bulletin 94, 630-639.

Fort, X., Brun, J.P., Chaubel, F., 2004. Contraction induced by block rotation above salt (Angolan margin). Marine and Petroleum Geology 21, 1281-1294.

Fontas, P., Valery, P., Le Quellec, P., Mascle, A., Renard, V., Tardy, M., Biju-Duval, B., 1985. Multibeam bathymetric survey of the Leg 78A drilling area and comparison with the southern part of the Barbados Ridge deformation front. In: Biju-Duval, B., Moore, J.C., et al. (Eds.), Initial Reports DSDP, vol. 78A. US Govt. Printing Office, Washington, pp. 63-78.

Galindo-Zaldívar, J., González-Lodeiro, F., Jaboloy, A., 1993. Stress and palaeostress in the Betic-Rif cordilleras (Miocene to the present). Tectonophysics 227, 105-126.

Gutscher, M.-A., Malod, J., Rehault, J.-P., Contrucci, I., Klingelhoefer, F., Mondes-Victor, L., Spakman, W., 2002. Evidence for active subduction beneath Gibraltar. Geology 30, 1071-1074.

Hoernle, K., et al., 2003. Ostatlantik Mittlelmeer-Schwarzes Meer. Part 1. Cruise No. M51, Leg 1. 12 September-15 October 2001, WarnemendeMalaga. Meteor-Beriche 03-1, 38pp.

Keller, E.A., Pinter, N., 2002. Active Tectonics. Earthquakes, Uplift, and Landscape, second ed. Prentice-Hall, Upper Saddle River, NJ, 362pp.

Keller, J.V.A., Hall, S.H., Darrt, C.J., McClay, K.R., 1995. The geometry and evolution of a transpressional strike-slip system: SE Spain. Journal of Geological Society of London 152, 339-352.

López-Ruiz, Cebría, J.-M., Doblas, M., 2002. Cenozoic volcanism I: the Iberian peninsula. In: Gibbons, W., Moreno, T. (Eds.), The Geology of Spain. The Geological Society of London, pp. 417-438.

Maillard, A., Gaullier, V., Vendeville, B.C., Odonne, F., 2003. Influence of differential compaction above basement steps on salt tectonics in the Ligurian-Provencal, northwest Mediterranean. Marine and Petroleum Geology 20, 13-27.

Maldonado, A., Campillo, A.C., Mauffret, A., Alonso, B., Woodside, J., Campos, J., 1992. Alboran Sea Late Cenozoic tectonic and stratigraphic evolution. Geo-Marine Letters 12, 179-186.

Marín-Lechado, Galindo-Zaldívar, J., Rodríguez-Fernández, L.R., Serrano, I., Pedrara, A., 2005. Active faults, seismicity and stresses in an internal boundary of a tectonic arc (Campo de Dalías and Níjar, southeastern Betic Cordilleras, Spain). Tectonophysics 396, 81-96.

Martínez-Díaz, J.J., 2000. Actividad neotectónica en el sureste de Almería y su incidencia en la morfotectónica de la zona (Cordillera Bética). Revista de la Sociedad Geologica de España 13, 417-429.

Martínez-Díaz, J.J., Hernández-Enrile, J.L., 2004. Neotectonics and morphotectonics of the southern Almería region (Betic CordilleraSpain) kinematic implications. International Journal of Earth Sciences 93, 189-206.

Mauffret, A., El-Robrini, M., Gennesseaux, M., 1987. Indsice de la compression récente en mer Mediterranée: un basin losangique sur la marge nord-algérienne. Bulletin de la Societe Geologique France 6, 1195-1206.

Medialdea Vega, J., Baena Pérez, J., Garcia Rodríguez, J., Maldonado Lopez, A.E., Uchupi, E., Udias Vallina A., Wandossell Santamaria, J., 1982. Mapa geológico de la plataforma continental Española y zonas adyacentes. E: 1:200,000. Almería-Garrucha. Chella-Los Genoveses. Instituto Geológico y Minero de España, 105pp.

Montenet, C., Ott d'Estevou, P., Masse, P., 1987. Tectonic sedimentary characters of the Betic Neogene basins evolving in a crustal transcurrent zone (SE Spain). Bulletin du Centre Recherche Exploration-Production Elf Aquitaine 11, 1-22.

Morel, J.-L., Meghraoui, M., 1996. Goringe-Alboran-Tell tectonic zone: a transpression system along the Africa-Eurasia plate boundary. Geology 24, 755-758. 
Muñoz, A., Ballesteros, M. Montoya, I., Ribera, J., Acosta, J., Uchupi, E., in press. Alborán Basin, southern Spain. Part I: geomorphology. Marine and Petroleum Geology, doi:10.1016/j.marpetgeo.2007.05.003.

Negredo, A.M., Bird, P., de Galdeano, C.-S., Buforn, E., 2002. Noetectonic modeling of the Ibero-Maghrebian region. Journal of Geophysical Research 107, ETG1-10-ETG1-15.

Oldow, J.S., Bally, A.W., Avé Lallemant, H.G., 1990. Transpression, orogenic float, and lithospheric balance. Geology 18, 991-994.

O'Reilly, B.M., Readman, P.W., Shannon, P.M., Jacob, A.W.B., 2003. A model for the development of a carbonate mound population in the Rockall Trough base don deep-towed sidescan sonar data. Marine Geology 198, 55-66.

Pérez-Belzuz, F., 1999. Geología del margen y cuenca del Mar de Alboran durante el Plio-Cuaternario: sedimentación y tectónica. Ph.D. Thesis, University of Barcelona, 538pp.

Platt, J.P., Vissers, R.L.M., 1989. Extensional collapse of thickened continental lithosphere: a working hypothesis for the Alboran Sea and Gibraltar arc. Geology 17, 540-543

Platt, J.P., Whitehouse, M.J., Kelley, S.P., Carter, A., Hollick, L., 2003. Simultaneous extensional exhumation across the Alboran Basin: implications for the causes of late orogenic extension. Geology 31, 251-254.

Rodríguez-Fernández, J., Martín-Penela, A., 1993. Neogene evolution of the Campo de Dalías and the surrounding offshore areas (northeastern Alboran Sea). Geodinámica Acta 6, 255-270.

Rodríguez-Fernández, J., Comas, M.C., Soría, J., Martín-Pérez, J.A., Soto, J.I., 1999. The sedimentary records of the Alboran Basin: an attempt at sedimentary sequence correlation and subsidence analysis. In: Zahan, R., Comas, M.C., Klaus, A. (Eds.), Proceedings of the Ocean Drilling Program, Scientific Results, vol. 161. College Station, TX, pp. 69-76.

Rodríguez-Fernández, J., Azanon, J.M., Martinez-Martinez, J.M., 2000. Plio-Quaternary contractive reorganization along the Serrata-Carboneras Fault zone, NE Alboran Basin (abs.). Geological Processes on European Continental Margins 168, 28.
Shipboard Scientific Party, 1996. Introduction. In: Zahn, R., Comas, M.C., Klaus, A. (Eds.), Proceedings of the Ocean Drilling Program, Initial Reports, vol. 161. College Station, TX, pp. 5-19.

Srivastava, S.P., Roest, W.R., Kovacs, L.C., Oakey, G., Lévesque, S., VBerhoef, J., Macnab, R., 1990. Motion of Iberia since Late Jurassic: results from detailed aeromagnetic measurements in the Newfoundland Basin. Tectonophysics 184, 229-260.

Stapel, G., Moeys, R.P., Biermann, C., 1996. Neogene evolution of the Sorbas basin (SE-Spain) determined from paleostress analysis. Tectonophysics 255, 291-305.

Sylvester, A.G., 1988. Strike-slip faults. Geological Society of America Bulletin 100, 1666-1703.

Tchalenko, J.S., Ambraseys, M.N., 1970. Structural analysis of the Dashte Bayaz (Iran) earthquake fractures. Geological Society of America Bulletin 81, 41-60.

Vegas, R., 1992. Sobre el tipo de deformación distribuida en el contacto entre África y la Península Ibérica. Física de la Tierra 4, 41-56.

Vegas, R., Vázquez, J.T., Medialdea, T., Suriñach, E., 1995. Seismic tectonic interpretation of the ESCI-Béticas and ESCI-Alborán deep seismic reflection profiles: structure of the crust and geodynamic implications. Revista de la Sociedad Geologica de España 8, 449-460.

Watts, A.B., Platt, J.P., Buhl, P., 1993. Tectonic evolution of the Alboran basin. Basin Research 5, 153-177.

Wilcox, R.E., Harding, T.P., Seely, D.R., 1973. Basic wrench tectonics. American Association of Petroleum Geologists Bulletin 57, 74-96.

Woodside, J.M., Maldonado, A., 1992. Styles of Compressional Neotectonics in the Eastern Alboran Sea. Geo-Marine Letters 12, $111-116$.

Zazo, C., Silva, P.G., Goy, J.L., Hillaire-Marcel, C., Ghaleb, B., Lario, J., Bardají, T., González, A., 1999. Coastal uplift in continental collision plate boundaries: data from the last interglacial marine terraces of the Strait of Gibraltar area. Tectonophysics 301, 95-109. 